\title{
Wage Inequality and the Labour Market in Argentina: Labour Institutions, Supply and Demand in the Period 1980-99*
}

\author{
Sebastián Waisgrais \\ Department of Economics \\ Universidad Pública de Navarra \\ sebastian.waisgrais@unavarra.es
}

October 2002

\footnotetext{
* This study was written during my stay at the International Labour Organization's International Institute for Labour Studies in Geneva, under the auspices of the Phelan Fellowship Programme. I would like to take this opportunity to express my thanks for the support I received from all members of the Institute and from those attending the IILS Workshop, Geneva, 2001.

I should particularly like to thank Jean-Michel Servais, David Kucera, Rolph van der Hoeven, Pedro Pascual, Joseba de la Torre, Emilio Domínguez and Enrike Galarza for their very constructive comments on this study. Once again, I am indebted to Rosalia Cortés and Adriana Marshall for their confidence and their invaluable support. It only remains to add that any errors or omissions are the exclusive responsibility of the author.
} 


\begin{abstract}
The present study is concerned with the economic and institutional factors affecting the relationship between the labour market and wage inequality in the Greater Buenos Aires area ("GBA") over the period 1980-99. The main hypothesis advanced is that the variations in levels of wage inequality were caused by changes in economic conditions and by the reforms implemented in the labour market, which were key factors in the process of wage determination and in the generalization of atypical and precarious forms of employment that impacted upon the distribution structure. In particular, the study considers long-term trends in wage inequality affecting employees in Greater Buenos Aires and the development of the labour market in the light of the institutional and economic factors that are relevant to wage inequality. In the empirical analysis, various econometric models are applied and the Theil index is broken down over population subsets defined in accordance with the employees' economic, demographic, labour and human resources characteristics.
\end{abstract}

Keywords: Labour Market, Wages, Inequality, Labour Institutions

JEL Codes: J2, J5, J31, C30 


\section{INTRODUCTION}

The purpose of the present study is to examine the main determinants affecting the variations in wage inequality in Argentina over the period 1980-99. During the mid-1970s, a structural change took place in the Argentinian distribution pattern: from being a country of moderate inequality by Latin American standards, Argentina became one of the group of countries where levels of inequality were highest. The main hypothesis advanced in this study is that the variations in levels of wage inequality were caused by institutional and economic changes generated in the labour market. First, the economic policies that were applied from the early 1980s onwards, together with the various economic crises, affected the economy, the labour market and, especially, the distribution structure. In the 1990s, this trend was reinforced as a result of policies of liberalization that brought a degree of economic stability, with periods of revived investment and output, although there were also "adverse effects" - or more pronounced adverse effects in some cases - resulting primarily from the decline of formal employment. Secondly, the period under review was characterized by institutional reforms and interventions in the labour market, which were key factors in the wage determination process and in the generalization of atypical and precarious forms of employment that impacted upon the distribution structure. Overall, the result of a process of crises and of economic and institutional (labour and social security) reforms is a labour market characterized by flexible, limited-term and insecure contractual arrangements as well as by the results of government schemes for the creation of temporary employment, with predictable consequences for the distribution structure.

The magnitude of the worsening of wage distribution, and its consequences for the welfare of the population, prompted us to inquire into the reasons for this process, starting from an analysis of the labour market. The questions which gave rise to this study, and which it endeavours to answer, are as follows. Can the increase in inequality be explained by the type of state intervention, the changes in labour legislation and the institutional reforms introduced in the labour market? What is the role of the labour institutions in determining wage inequality? What is the relationship between the changes that took place in the composition of labour supply and demand and wage inequality? What has been the impact of macroeconomic policies on the distribution structure? And, especially, why are policies designed to adjust the employment market promoted and implemented in a context of high economic growth?

The main focus of analysis will be the employed sector of the economy. Various factors play a part in the variations in inequality, but there is no doubt that possession of a job guarantees some degree of social integration. Paid employment, as stated by Castel (1997), was the mechanism of social integration during a large part of the twentieth century. Argentina was no exception: although the employed sector has been affected in recent years, especially in the lower wage strata, it nevertheless accounts for over $70 \%$ of total employment. ${ }^{1}$

This study comprises six sections, in addition to this introduction, as described in detail below. The second section comprises a review of the main studies of wage inequality and a brief summary of the principal hypotheses analysed. The third section provides a description

\footnotetext{
1 According to October 1999 figures, waged employment accounts for 65\% of employment in the poorest quintile, $80 \%$ in the intermediate quintiles and $69 \%$ in the richest quintile of distribution.
} 
of the data used and of the universe of analysis of the present study. The fourth section contains a historical account of wage inequality, an explanation of the methodology adopted together with a description of the indicators used, and finally an analysis of long-term trends in wage inequality as it affects employees in Greater Buenos Aires (the city of Buenos Aires and parts of the conurbation). The fifth section examines the evolution of the labour market in the light of the institutional and economic factors that are most relevant to wage inequality. Under the heading of institutional factors, the study considers the main aspects of state intervention in the labour market, from the standpoint of the political framework, the forms of intervention, the existence of collective bargaining and the labour legislation applied. In this context, particular attention is paid to developments in collective bargaining and minimum wage policies in Argentina. The economic factors analysed in this section are the components of labour supply and demand, the way in which employment responds to the economic cycles, and the changes that have taken place in the productivity of labour. Section six defines various econometric models, with a view to explaining wage inequality in the long term. As an alternative form of explanation for inequality, a decomposition of the Theil index is provided, based on population subsets defined in terms of economic, demographic and labour characteristics. Finally, conclusions are presented.

\section{PREVIOUS STUDIES OF WAGE INEQUALITY}

The effects of labour changes on wage inequality have attracted a considerable amount of research over the past twenty years. However, there has been a wide degree of diversity in the theoretical specifications used and the empirical models assessed. Probably, the consensus is that there is no such thing as a single analytical model and, in general, the emphasis is placed on the empirical aspect of the determinants of inequality.

For the purposes of this study, we have undertaken an extensive bibliographical review of the literature on wage inequality and its connection with the labour market; reference will be made to that review throughout the study. Nevertheless, in the interests of greater clarity, we have provided a brief summary of the main hypotheses analysed, reproduced in table 1.

In the course of these inquiries we encounter a "central core" comprising three sets of hypotheses that endeavour to explain the problem: those relating to the changes brought about in the principal labour institutions; those that focus on the demand components; and, finally, factors relating to the supply of labour.

The institutional components studied are closely linked to trade union activity and the changes that have taken place in respect of the minimum wage. The relative dominance of those two components of the labour market in this study arises from the reforms introduced in the United States and the United Kingdom during the 1980s. The consistency of the results of these inquiries, using different methodologies and sources of information, is very striking. The institutional components studied are relevant to an explanation of wage inequality. 
Table 1

Hypotheses used to explain wage inequality

\begin{tabular}{|c|c|}
\hline \multicolumn{2}{|c|}{ Erosion of the labour institutions } \\
\hline Minimum wage & Lee (1999); Machin (1997) \\
\hline $\begin{array}{l}\text { The changes in the real minimum wage produce } \\
\text { substantial modifications in the lower part of the wage } \\
\text { distribution, being a tool of containment for low-waged } \\
\text { workers. }\end{array}$ & $\begin{array}{l}\text { Fortin and Lemieux (1997) } \\
\text { Dinardo and Lemieux (1997) } \\
\text { Card and Krueger (1995) } \\
\text { Freeman (1996) }\end{array}$ \\
\hline $\begin{array}{l}\text { Effects of trade union activity } \\
\text { Greater trade union coverage and density generate greater } \\
\text { benefits for poorly qualified workers together with wage } \\
\text { increases for workers with union coverage. }\end{array}$ & $\begin{array}{l}\text { Lewis (1986); Kahn (2000) } \\
\text { Freeman (1980, 1996) } \\
\text { Card (1992); Machin (1997) } \\
\text { Dinardo and Lemieux (1997) } \\
\text { Fortin and Lemieux (1997) } \\
\end{array}$ \\
\hline $\begin{array}{l}\text { Decentralization of collective bargaining } \\
\text { The decentralization of collective bargaining generates } \\
\text { wage changes at company level that seem to have a greater } \\
\text { impact in the lower part of the distribution, significantly } \\
\text { increasing wage dispersion. }\end{array}$ & $\begin{array}{l}\text { David and Haltiwanger (1991) } \\
\text { Blau and Kahn (1996) } \\
\text { Elliot and Bender (1997) }\end{array}$ \\
\hline \multicolumn{2}{|l|}{ Demand factors } \\
\hline $\begin{array}{l}\text { Technological change } \\
\text { Especially in developed countries, technological change } \\
\text { benefits highly educated workers, thus generating an } \\
\text { increase in wage differentials. }\end{array}$ & $\begin{array}{l}\text { Bound and Johnson (1992) } \\
\text { Katz and Murphy (1992) } \\
\text { Krueger (1993) } \\
\text { Goux and Maurin (2000) } \\
\end{array}$ \\
\hline $\begin{array}{l}\text { Commercial openness } \\
\text { The lowering of international barriers to trade has } \\
\text { increased the effective availability of goods produced by } \\
\text { workers with low levels of qualification. }\end{array}$ & $\begin{array}{l}\text { Goux and Maurin (2000); Cornia } \\
\text { (1999) } \\
\text { Forbes (2000); Robertson (2000) } \\
\text { Kanbur and Lusting (1999) } \\
\text { Galiani and Sanguinetti (2000) } \\
\end{array}$ \\
\hline \multicolumn{2}{|l|}{ Supply factors } \\
\hline $\begin{array}{l}\text { Increase in size of workforce (especially women) } \\
\text { Women are competing with low-waged, poorly qualified } \\
\text { men and, by a process of substitution, inequality is } \\
\text { increased, particularly among men. }\end{array}$ & $\begin{array}{l}\text { Tzannatos (1999) } \\
\text { MacPhail (2000); Topel (1997) } \\
\text { Juhn and Kim (1995) } \\
\text { Fortin and Lemieux (1997) } \\
\end{array}$ \\
\hline Increased immigration & Borjas et al. (1992) \\
\hline $\begin{array}{l}\text { An influx of workers from other countries (especially } \\
\text { developing countries) reduces wages in the sectors where } \\
\text { the increase in supply occurs. }\end{array}$ & Topel (1997) \\
\hline \multicolumn{2}{|l|}{ Other factors } \\
\hline $\begin{array}{l}\text { Changes in the fabric of industry } \\
\text { Loss of manufacturing jobs. }\end{array}$ & $\begin{array}{l}\text { Bernard and Jensen (1998) } \\
\text { MacPhail (2000) }\end{array}$ \\
\hline $\begin{array}{l}\text { Government deregulation } \\
\text { Government deregulation in the industri }\end{array}$ & Fortin and Lemieux (1997) \\
\hline
\end{tabular}

The second group of explanations are linked to demand components. One of the more recent phenomena in the labour market is the increase in demand for highly educated workers, while demand is falling in the low-qualified sectors; the numbers of people returning to education are increasing. The critical factors used by the various studies to try to account for this phenomenon are technological change and commercial openness, relatively recent effects 
that are closely linked to the globalization of production in the international markets. ${ }^{2}$ In the case of technological change, the various studies note that the use of technologies has caused a shift in demand towards better educated workers, thus generating an increase in the education premium. As far as trade movements are concerned, the majority of studies take the Heckscher-Ohlin model as their starting point. 3 The empirical evidence of this model, in relation to inequality, shows that those most damaged by increasing openness are unskilled workers, and that these effects are relatively permanent in character.

On the supply side, the increase in labour market participation and migratory movements are the factors that have most often been cited in explanations of wage inequality. Labour market participation, especially by women, has increased steadily over the past two decades. The possible impact on inequality is claimed to be that women are competing in the labour market with low-waged and poorly qualified men and are thus increasing inequality, especially among men, by a process of substitution. However, the empirical results would not appear to bear out this hypothesis. As far as migratory movements are concerned, there is a great deal of ambiguity in the results obtained, although the tendency is to suggest that this is a very weak factor for the purposes of explaining wage inequality.

Finally, we should draw attention to two additional hypotheses whose evaluation has produced interesting results. The first is the effect on wage inequality of the composition of industry, and specifically the role of deindustrialization processes on the distributional structure. Bernard and Jensen (1998) find that, in the case of the United States, there is a negative correlation between the decline of industrial employment and increases in inequality, independently of all the specifications studied. Secondly, Fortin and Lemieux (1997) analyse the policies of deregulation in the sectors of industry where they have been applied and their influence upon wage inequality in sectors covered and not covered by trade union activity. 4 The findings of that study are that the impact of deregulation is slight in terms of explaining overall wage inequality. The effect is more significant for men who are covered by union activity, owing to the fact that this sector was the most severely damaged by the deregulatory measures.

\section{DATA}

The Encuesta Permanente de Hogares (Continuous Household Survey - "EPH") is the main source of information for the calculation of inequality indicators and socio-labour variables. The EPH is a continuous survey undertaken by the Argentinian Instituto Nacional

2 As stated by Freeman and Katz (1994), increasing international competition might motivate companies to innovate, adapt to new technologies or change their work organization. And technological changes affect trade patterns. Thus, one of the fundamental problems with this explanation is the separation of the effects on wage inequality of technology and trade.

3 This model demonstrates that comparative advantage depends on the interaction between national resources (relative abundance of production factors) and production technology (which influences the relative intensity with which the various production factors are used) (Krugman and Obstfeld, 1994). The result is that countries will tend to export goods that make intensive use of their abundant factors and to import goods that make intensive use of the factors with which they are poorly endowed.

4 The deregulated sectors are included among the group where union presence is strongest; the ultimate effect will depend upon how union activity and bargaining power have resisted policies of deregulation. 
de Estadística y Censos (National Statistical and Census Institute - "INDEC") since 1972. The survey is constructed on the basis of a probability sample and is updated every six months (in May and October). ${ }^{5}$ The EPH includes variables relating to households and to individuals. It provides a classification of the population in terms of demographics, occupation, housing, education and income.

The universe of analysis for the empirical study is Greater Buenos Aires, since this is the only urban environment for which it is possible to construct relatively extensive time series. This is not a serious limitation, since approximately $40 \%$ of the Argentinian population is concentrated within the GBA conurbation, so that, with appropriate precautions, it is possible to extrapolate the conclusions to the population as a whole.

Secondary sources of information are the employment statistics produced by the Economic Commission for Latin America and the Caribbean (ECLAC) and the Argentinian Ministry of Labour and Ministry for Economic Affairs, and the publications of national accounts by the Argentinian Central Bank (BCRA) and ECLAC.

\section{WAGE INEQUALITY}

\subsection{Historical context}

The situation in Argentina can be described as paradoxical. It is a country with a great abundance of resources (natural, human and production) and no significant demographic problems, and is the front runner among countries in the region in establishing institutions associated with the provision of public and social benefits and services. Nevertheless, it has proved unable to generate a sustainable process of development. Its recent history, at least in terms of certain economic and distributive characteristics, can be divided into two distinct periods. During the first, which began in the 1930s and continued until the mid-1970s, the economic policies applied, characterized by a process of industrialization, achieved high levels of social integration, employment levels bordering on full employment, very low levels of underemployment and low income differentials. There were no supply or demand pressures in the labour market, the process of urbanization and industrial dynamism generated sufficient jobs, and the rate of growth of the economically active population ("EAP") was low, so that supply also increased slowly and levels of underutilization were relatively insignificant. This situation, combined with the high productivity of the agricultural and cattle breeding sector, generated a development dynamic where problems of employment and distribution were not particularly significant. 6

The mid-1970s brought the first indications that this pattern of development was beginning to lose impetus. Output began to stagnate, producing a similar effect on formal

\footnotetext{
5 Since 1998 an additional survey has been carried out in August.

${ }^{6}$ Moreover, as noted by Altimir and Beccaria (1999), the process of European immigration during this period produced various types of demographic impact that had a favourable influence on the labour market. The immigrants tended to settle in urban areas, resulting in a significant process of urbanization. Between 1914 and 1970, the national censuses show that the urban population increased from $58 \%$ to $79 \%$. The state education system, in turn, was propitious to a rise in the educational standard of the labour supply, allowing better integration into the increasing dynamism of industry and the services sector.
} 
labour demand. The proportion of the total workforce represented by employees began to fall, and there was a rise in unemployment to around 5\%. The process of import substitution in the basic industries had not been entirely completed, and the margin for replacing imported production with domestic production was already very narrow (Gerchunoff and Llach, 1998). Inflation, too, began to exercise a major structural constraint on the economy of Argentina. ${ }^{7}$

Chart 1

\section{Inequality trends in 8 Latin American countries 8}

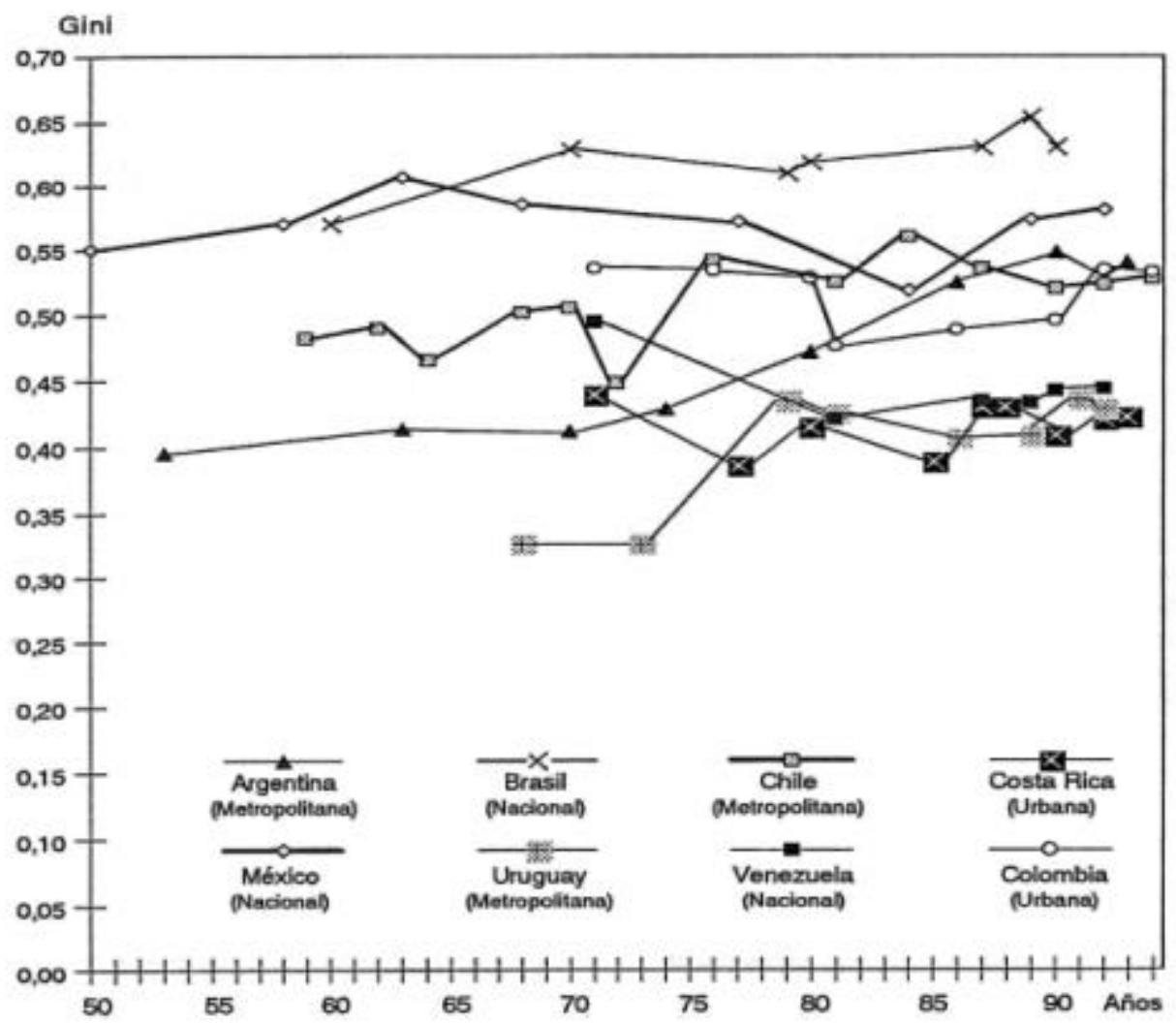

Source: Altimir (1997).

There is a degree of consensus among some authors (Altimir, 1986; Marshall, 1995; Beccaria, 1991) that during those years, and after 1975, a change took place in the distribution structure. Argentina, which until the mid-1970s had been one of the countries where inequality was moderate and relatively stable, with Gini coefficients similar to those of Costa Rica and Uruguay, became one of the high-inequality states from the beginning of the 1990s (chart 1). The increase in wage dispersion levels was not specific to the Argentinian economy but affected most countries in the region, to a greater or lesser degree and subject to the specific features of each. 9 A survey of recent figures shows that in the early 1990s Latin

\footnotetext{
7 The average annual rate of inflation in the period $1930-40$ was $-0.6 \%$. In $1940-9$ it was $11.2 \%$, in $1949-63$ it reached $26.3 \%$, and eventually for $1963-73$ it was $30 \%$.

8 Altimir (1997) took as his reference group the entire employed population, using the reference variable of per capita income, so that the values of the coefficient differ from those used in this study.

9 Beccaria (1991) maintains, however, that the phenomenon as it affected Argentina exhibited different characteristics from the traditional Latin American stereotype, since a substantial part of it derived
} 
America as a whole still had the highest level of inequality of any region in the world. The mean Gini coefficient for the countries in the region is 0.49 , more than 15 points above that of the developed countries or the states of south-east Asia and comparable only with the figure for the African countries (Székely and Londoño, 1998).

\section{Chart 2}

\section{Lorenz curve - GBA, employees, 1974, 1991 and 1999}

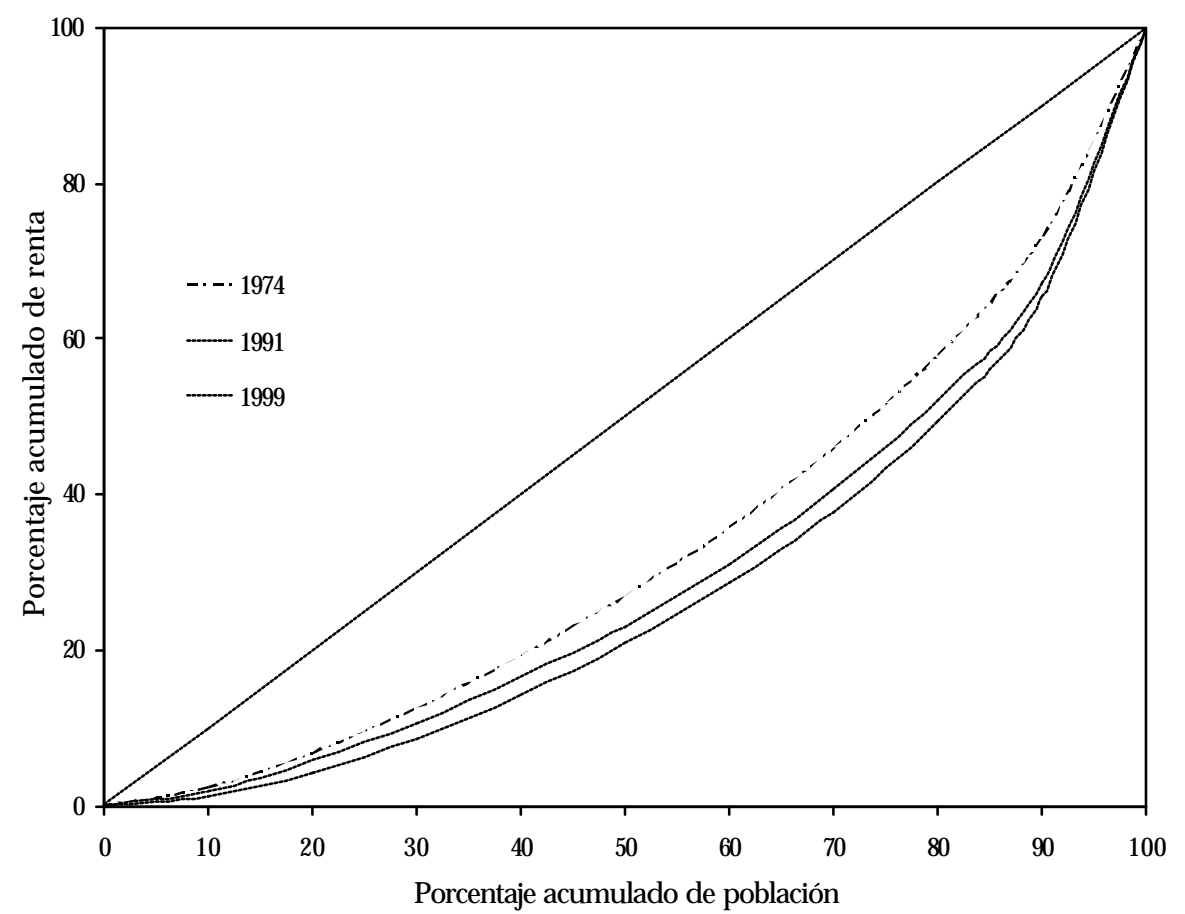

Source: Author's calculations based on EPH, INDEC.

The abrupt change that took place after the mid-1970s has been analysed by various authors, and their findings have displayed some consistency. Beccaria (1991) and Altimir (1986) find that the worsening distribution cannot be regarded merely as a cyclical episode, but is the product of a structural process, identified by them as comprising the fall in the average wage, changes in the framework for determining pay, and restrictions on wage negotiation. Along the same lines, Marshall (1995) concluded that government intervention had played a dominant part in causing the increase in inequality of distribution through the policy of wage control. This effect was particularly apparent during the period 1976-82, but also helps to explain the distribution results in 1985-7 and again in 1991-3. The author adds that during the most recent period of military government (1976-83) a reduction in the wage bill was perceived as a condition for growth, so that wages were very strictly controlled. As a result of these policies, the fall in real wages between 1975 and 1976 alone was of the order of $30 \% .10$ This hypothesis of the change in the part played by the State is also advanced by Hidalgo (1999). He maintains that, from the time of the conservative policies of 1976, the State lost its central function as an "arbitrator" and became a force for the perpetuation of instability rather than for the resolution of distribution conflicts. Altimir (1997) and Iglesias

from the process of impoverishment that accompanied the fall in the average income and worsening pattern of distribution.

10 Our calculations show that if the period of analysis is extended to include 1978 , the fall was $42 \%$. 
(1998) believe that the various stages of increasing inequality were significantly influenced by the economic cycles (internal imbalances and external shocks) and the abrupt changes in per capita income in the 1970s and 1980s.

Chart 2 shows the Lorenz curves for the years 1974, 1991 and 1997. ${ }^{11}$ These curves show the process of increasing inequality between the mid-1970s and late 1990s, demonstrating that both the costs of the economic crises and adjustments of the 1980s and those of the reform process of the 1990s were distributed very unequally. On the other hand, in accordance with the findings of Shorrocks (1980), we can say that the increase in levels of inequality exhibits no ambiguity, since there are no apparent breaks in the curves in any segment.

It was not only the low-waged sectors that saw a decline in their relative share of distribution. Those including $60 \%$ of recipients of middle-range incomes also experienced a fall in their share of the distribution. In other words, the steady deterioration of the economic situation had an impact on the middle class as well. As is shown in table 2, there is a downward trend in these income strata. Between the two extremes there is a $32 \%$ fall in the share of the poorest $30 \%$ and a $7 \%$ fall for the middle $60 \%$, while the highest income bracket increased its share by $30 \%$.

To summarize, although the process of inequality affecting the labour market has worsened in recent years, its roots are structural, typified by adverse economic factors, the forms of state intervention in the labour market, and in particular the decline in the average wage.

Table 2

Wage distribution in the employed population, GBA 1974-99, in \%

\begin{tabular}{r|r|r|r}
\hline Year & Poorest $30 \%$ & Middle $60 \%$ & Richest $10 \%$ \\
\hline 1974 & 12.6 & 60.5 & 26.9 \\
\hline 1980 & 11.5 & 57.1 & 31.4 \\
\hline 1986 & 10.9 & 56.4 & 32.7 \\
\hline 1991 & 11.0 & 55.8 & 33.2 \\
\hline 1994 & 10.9 & 56.2 & 32.9 \\
\hline 1997 & 9.9 & 56.7 & 33.4 \\
\hline 1999 & 8.6 & 56.8 & 34.6 \\
\hline
\end{tabular}

Source: Author's calculations based on EPH-INDEC.

\subsection{Towards a new economic model?}

The 1990s began with the reform process. As in the majority of Latin American companies, the reforms, based on the "Washington Consensus", 12 did bring economic stability

11 The Lorenz curve is an indicator of the degree of wage dispersion. It relates percentages of the total wage to percentages of the population on the basis of a non-decreasing order of the per capita income vector, so that the curve shows the cumulative percentage of income corresponding to the percentile $\rho$ of per capita income distribution, $0 \leq \rho \leq 1$ (Goerlich, 1999).

12 The "Washington Consensus" is the name given to the agreement on desirable economic reforms for the debtor states of Latin America, urged by the International Monetary Fund and the World Bank. Williamson (1996) lists ten principles of policy on which he considers a consensus has been reached. 
and periods of revived investment and increased output. Nevertheless, they also produced and in some cases reinforced - "adverse effects" in the form of a reduction in formal employment and increases in wage inequality.

Although the reforms might have been designed to promote the conditions for stable growth, and to encourage a more open and competitive economy in an international context that was beginning to be dominated by the effects of globalization, the strategy pursued when it came to implementing the changes simultaneously on all fronts gave rise to social restrictions, owing to the fact that the compensatory effects were insufficiently far-reaching. ${ }^{13}$ Furthermore, the system based on openness, a (long-term) fixed exchange rate with a foreign exchange deficit and relative price adjustments against tradable goods affected employment levels and to some extent tended to reverse the effects of the actual reforms. Companies reacted to their losses of market share by resorting to various mechanisms to reduce labour costs: they lobbied for new labour regulations, ${ }^{14}$ increased the hourly workload of those who were in work, or even went so far as to replace local workers with recent migrants from neighbouring countries, Not only that, but, as noted by Barbeito and Rodríguez (1997), the manufacturing sectors saw adjustments to company workforces, a reduction in the number of employees by means of greater use of imports in the production processes, the shutting-down of production lines and the substitution of inputs of domestic origin, which led to global restructuring and had a particular impact on industry. The "official" interpretation of the problems caused by openness was to attribute them to a combination of low competitiveness and high labour costs, which created a climate propitious to companies' demands for new reforms (from 1995 onwards), more specific ones on this occasion, to reduce wage and nonwage costs.

The labour market scenario left by the reforms is one in which precarious employment not only has not been reduced but has actually increased, the rises in employment in recent years being explained by flexible, limited-term contracts and insecure employment in general, new forms of "atypical" employment which have had a negative impact on the problem under consideration here.

\subsection{Methodology for calculating the wage inequality indicators}

The usual approach to measuring wage inequality is to determine the degree of dispersion of wages relative to a reference value - for example, the average wage, a theoretical situation of equality where all workers are paid the same wage. However, as noted by Adelman and Morris (1974), a feature of "inequality" is that it is multidimensional, so that

\footnotetext{
The objective is the replacement of protectionist arrangements with non-interventionist models that are outward-looking and geared to the establishment of free market capitalism. In view of this, some authors (Bulmer-Thomas, 1996) define the scope of these policies as the "New economic model in Latin America".

13 Gwynne and Kay (2000) analyse why the shock tactics spread so rapidly in Latin America. One possible explanation is the failure of the first "heterodox" stabilization plans (Austral in Argentina, Cruzado in Brazil). The high inflationary trends that followed in the wake of those plans persuaded the population that the "bitter pill" had to be swallowed.

14 Introduction of limited-term contracts with reduced employers' contributions to the pension system, a reduction in the costs of dismissal and compensation payable for accidents at work, etc.
} 
it can be measured by various methods, none of which is valid for all purposes. ${ }^{15}$ In this study, four indicators are used for the calculation of inequality: the Atkinson, Gini and Theil coefficients, and the ratio between quintile 5 and quintile 1 of the distribution. A description of the calculated indicators is given below.

\section{Atkinson coefficient}

The coefficient proposed by Atkinson (1970) is obtained from a function of social welfare of a utilitarian type:

$$
W(x)=\sum_{i=1}^{n} c_{i}^{1-\varepsilon}+b \quad \text { where } \varepsilon>0
$$

Thus the Atkinson index is defined as:

$$
A(\varepsilon)=1-\left[\sum_{i=1}^{n}\left(x_{i} / \bar{x}\right)^{1-\varepsilon} f_{i}\right]^{\frac{1}{1-\varepsilon}} \quad \text { where } \varepsilon \geq 0
$$

The coefficient uses an explicit parameter to introduce a distributional objective. This parameter represents society's aversion to inequality. In our case, the parameter takes four alternative values of $\varepsilon(=0.5,1.5,2.0,2,5)$. It is simple to interpret: it indicates the maximum quantity of income that must be given up in order to achieve equal distribution. If the value of $\varepsilon$ is close to 0 , society is indifferent to distribution. As the value of $\varepsilon$ increases, so too does the importance that society attaches to social welfare. As stated by Atkinson (1970), the extreme situation, with very high values of $\varepsilon$, could be identified with the function of welfare developed by Rawls (1972) in his contractual theory of justice, where inequality is measured in terms of the position of the most disadvantaged members of society. 16

\section{Gini coefficient}

Considering an economy with $n$ individuals where $y_{i}$ is the income of individual $i$ ( $i=$ $1,2, \ldots . n) ; y$ is the vector $\left(y_{1}, y_{2}, \ldots, y_{n}\right)$ which summarizes the distribution and $\bar{y}$ is the average income, then the Gini coefficient is defined as:

$$
G=\frac{1}{2 n^{2} \bar{y}} \sum_{i=1}^{n} \sum_{j=1}^{n}\left|y_{i}-y_{j}\right|
$$

\footnotetext{
15 The significance of various measurements of inequality is discussed in the works of, inter alios, Atkinson (1970) and (1975), Foxley (1974), Goerlich (1998) and (1999) and Zubiri (1985).

16 This is an interesting distinction: Rawls (1972) defines the principles that regulate the distributional structure of society. Specifically, according to Rawls, it is the second principle of justice, defined as the "principle of difference", that is closely related to the Atkinson coefficient with high values of $\varepsilon$, in other words where society is very averse to inequality.
} 
The results given by the Gini index are simple to interpret. For continuous distributions, this indicator has a range of variation between 0 (where income is distributed on an egalitarian basis) and 1 (where concentration is extreme). As the indicator approaches unity, inequality is greater, and, conversely, when its values are close to 0 we are approaching a situation of equality. In geometrical terms, it can be illustrated by means of the Lorenz curve: the coefficient is the resultant of double the area contained between the Lorenz curve and the $45^{\circ}$ diagonal or total equality (chart 2).

\section{Theil entropy index}

The Theil entropy index (T), where $y_{i}$ is the total income of group $i, y$ is total income and $N$ is the total selected population, is defined as follows:

$$
T=\sum_{i=1}^{n} \frac{y_{i}}{y} \ln \frac{y_{i} N}{y}
$$

Entropy is understood as meaning the level of information expected from a distribution. Statistically, the entropy of a distribution is a measure of its dispersion: the greater the dispersion, the less the information that can be expected (Llach and Montoya, 1999). This indicator, similar to the Gini since both are weighted statistics, has the advantage of giving greater weighting to shifts taking place at low income levels.

\section{Equity indicator}

This indicator is defined as the coefficient between the shares of the last and first quintiles. It has certain disadvantages, explained by the shortcomings of the household surveys when it comes to defining, within a sufficient confidence interval, which are the pertinent sectors at the extremes of the distribution. As far as the lowest quintile is concerned, the major problem identified by Salama and Valier (1996) lies in the complexity of calculating accurately the poorest $20 \%$ in certain developing countries, because of the extent of own consumption among the low-income families. Something similar, but with more serious features, arises with the highest $20 \%$, owing to underdeclared income not recorded by the survey. If that underdeclaration exists, the magnitude of the indicator would be even greater. Finally, it could also be argued that an indicator which relates extreme quintiles could not record the shifts occurring between the other three, unconsidered quintiles, and that this could be of some importance for empirical analysis. Nevertheless, the magnitude of the coefficient is so considerable that we have included it among the computed indicators.

\subsection{Long-term inequality trends}

Chart 3 shows the values obtained by the various measurements of wage inequality calculated over the period 1980-99. In order to emphasize the trends, the values have been normalized to 1980 values. The Gini and Theil coefficients are shown in chart 3(a), while the values for the four alternatives of the Atkinson coefficient are presented in chart 3(b). It can 
be seen that the trend over the course of time is similar for all the measurements. The only slight difference occurs in the period 1986-7, where the Atkinson indices with weightings greater than 2 reflect a greater increase in inequality than do the Gini, Theil and Q5/Q1 indices.

At first sight, it is interesting to note the procyclical trends of inequality. The 1980s, a decade marked by various economic crises, price stabilization policies and even some attempt at redistribution, ended with the highest levels of wage inequality seen up to that time. In the decade that followed, the ascending and more erratic cycle continued in a similar manner to the 1980s, and indeed would appear not to have peaked as yet. However, the pattern of development is different: reforms have been implemented, prices have stabilized, but the "upward" convergence cycle has continued.

We can divide the reference period into three stages. During the first, extending until 1985, the inequality indicators remained stable. The second, comprising the period 1986-90, was dominated by a deep economic crisis and substantial increases in wage inequality. The third stage, from 1992 to 199, was the period of the economic reforms. During the first stage, the inequality indices displayed a steady and in some cases slightly downward trend: $-2.5 \%$ for the Gini coefficient, $-2.8 \%$ according to Q5/Q1 and an average of $-3 \%$ for the Atkinson coefficients. This plateau can be explained by the interaction of two processes that may have produced opposite effects and, to some extent, explain this stability of the calculated indicators. Between 1980 and 1982, Argentina, and the Latin American countries in general, suffered from the effects of what was referred to as the "debt crisis", which conditioned economic policies and brought about extensive stagnation of GDP, owing to the fact that the sums that had to be paid by way of external interest and debt repayments exceeded the ability to pay of any country in the region. ${ }^{17}$ This situation was counteracted from 1983 onwards, when, with the return to democracy, there was a clear intent to bring about redistribution through a more permissive labour policy and a set of economic policies - price controls, fixing of the interest rate and public service charges - which brought inflation under strict control (Cortés, 1996) and, to some extent, might have cushioned the effects of the crisis on the labour market and on levels of wage dispersion.

From 1986 onwards, and until 1990, the most immediately striking features are the peaks of the indices. This trend, associated with the process of hyperinflation, had a crippling impact on the incomes of the lowest quintiles, which had little protection against the "inflationary tax". The CPI recorded annual increases of 390, 5,000 and 1,400\% in the years 1988, 1989 and 1990 respectively. During that period, the factor that exerted the greatest influence on public welfare was the change in the real wage, which touched its lowest point in 1989. In a period of sharply rising inflation, and with a State that was determining the nominal increases in pay, the significant increase in wage inequality is hardly surprising.

\footnotetext{
${ }^{17}$ Lanyi (1987) explains this process as the result of attempts by developing countries to maintain high growth rates in a global economy characterized by slow and more competitive growth. Indebtedness became an additional impediment to growth for the debtor countries. The factor that triggered the crisis was the increase in the nominal interest rates that took place from 1980 onwards, with an impact on countries where debts had been contracted at variable interest rates.
} 


\section{Chart 3 \\ Measurements of wage inequality}

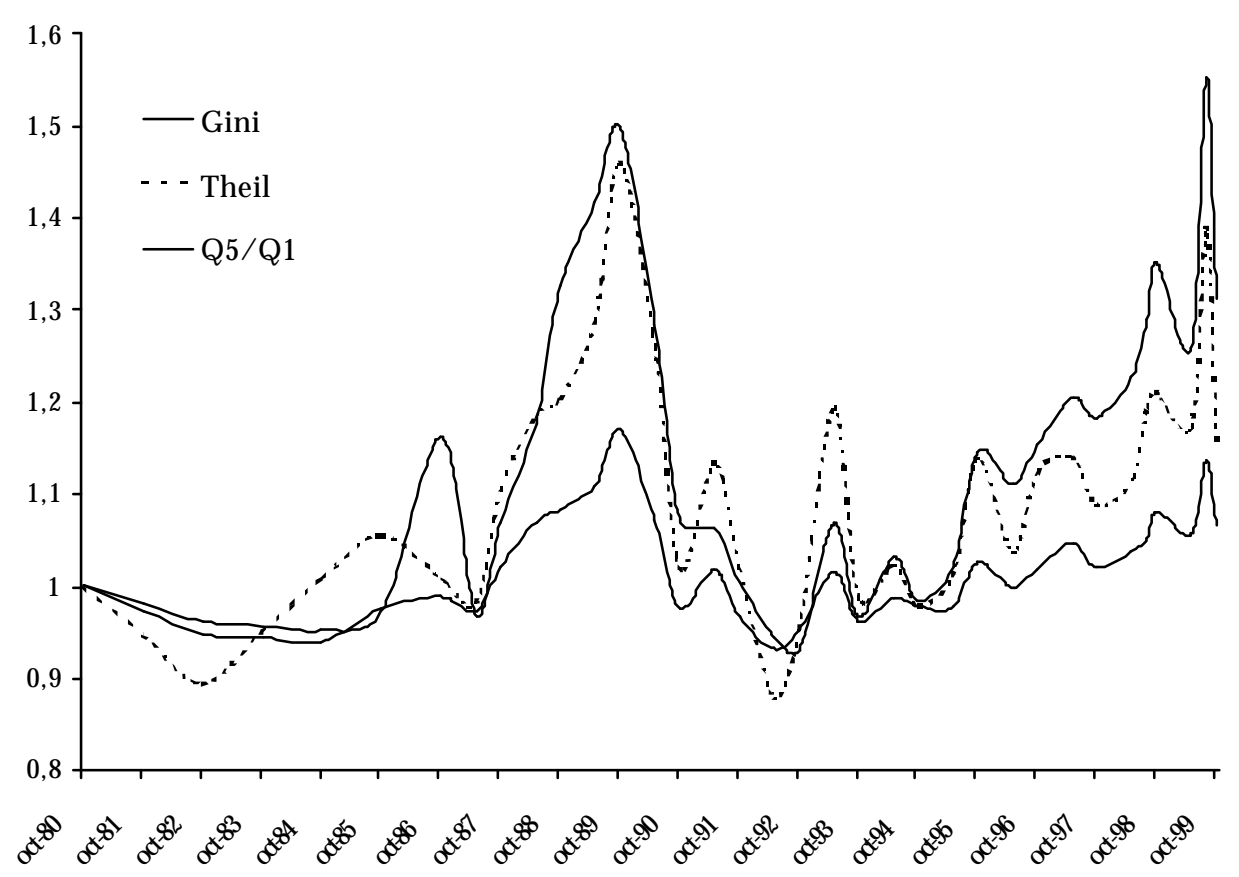

(a)

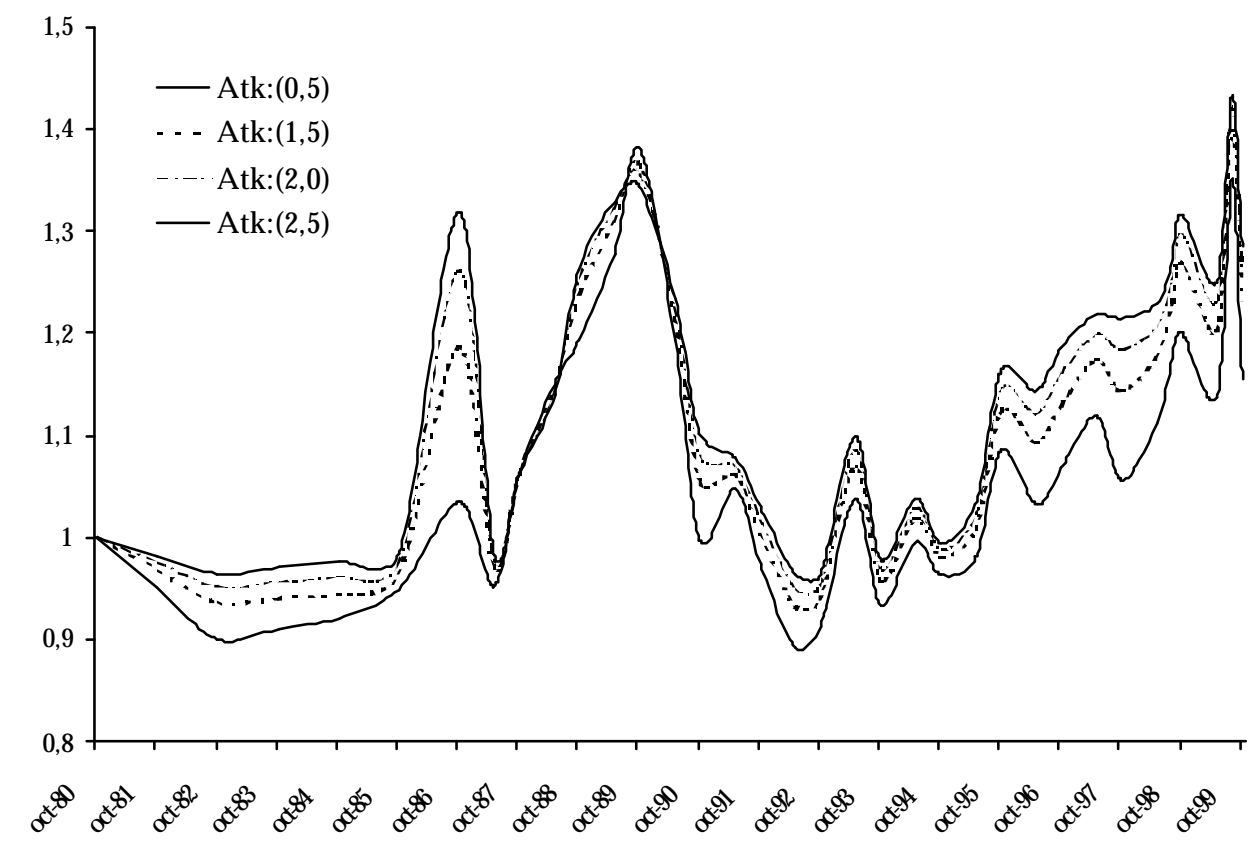

(b)

The years 1991-2 saw the beginning of the one of the most striking processes in terms of the effects of economic policies on wage distribution. In a climate of expansion, and with price stability achieved, the inequality indices rose continuously. Between 1991 and 1999, GDP rose by $42 \%$, consumption by $42.5 \%$, investment by $130 \%$ and exports and imports by $88 \%$ and $236 \%$ respectively. In the same period, the Gini coefficient increased by $14 \%$, the Theil by $32 \%$ and the gap between extreme quintiles by $38 \%$, while the average increase in the Atkinson measurements was $32 \%$. The dynamic overall production performance did 
nothing to improve levels of social welfare. In theoretical terms, and taking due account of the historical trend observed in Argentina (periods of expansion producing reductions in the level of inequality and vice versa), this marked a new departure, in the sense that it appeared that an increase in the incomes of the population was bringing about a reduction of inequality. This should have been reflected by an increase in per capita GDP and a fall in the Gini coefficient. However, as noted by Bustelo and Minujin (1996), that occurred only in some countries of the developed world and in south-east Asia.

The question posed by an analysis of this pattern is as follows: why, during a very dynamic period, was there a substantial increase in levels of inequality, to the point where they were even higher than they had been in the hyperinflationary period? Anticipating the answer, this study contends that certain economic factors and the reforms introduced in the labour market resulted in considerable labour segmentation, which had an adverse impact on the distribution structure.

\section{LABOUR MARKET AND WAGE INEQUALITY}

Many studies that set out to examine wage inequality on the basis of the behaviour of the labour market emphasize the analysis of economic factors such as the pattern of supply and demand, productivity, skill-biased labour demand, etc. Others, on the other hand, take as their starting point institutional factors such as legislative or state intervention in the labour market, the minimum wage, collective labour agreements, etc. From the economic standpoint, it can be argued that it is a high-risk approach to regard anything that cannot be explained, or even is generally difficult to quantify, as an institutional change. On the other hand, those who set out to analyse institutional changes as the dominant factor behind increases in wage dispersion contend that variations in levels of wage inequality require a more comprehensive approach than a simple analysis of supply and demand. Fortin and Lemieux (1997) adopt this line of reasoning when analysing the trend in wage inequality in the United States during the 1980s. Among the developed countries, this experience of a swift and sharp increase in wage inequality was almost unique. With the possible exception of the United Kingdom, ${ }^{18}$ no other developed country had experienced a situation of this kind, apart from the fact that the labour markets in the majority of the industrialized countries had suffered similar shocks and technological changes, so that, for example, an explanation based solely on demand could not satisfactorily account for these trends.

In the present work, it is argued that the two perspectives are mutually complementary, and certainly not contradictory. If we agree with Freeman (1996a) that the function of the labour institutions is to soften the adverse effects on wages of changes in supply and demand, both explanations (the economic and the institutional) apply with even greater force in the

\footnotetext{
18 The trend of inequality in the United Kingdom is further evidence of the effects of the policies applied during the 1980s. They reduced state participation and promoted the formation of capital, but at the cost of significant levels of inequality and unemployment. Other factors that help to explain the trend include cuts in social programmes, unemployment subsidies and the change in the basis whereby pensions were linked to the price index, resulting in significant falls in pensions (Kuhnle, 1997). Along the same lines, Castell and Bosch (1998) argue that the increase in the inequality of ultimate income was not due solely to the increase in wage inequality but also owed something to the reduced redistributive effect of budgetary policies.
} 
case of Argentina, since both factors moved in the same direction over the course of time. Simultaneously with the changes in supply and demand, the labour institutions were the subject of reforms, and their subsequent weakening meant that they were never able to fulfil their role of cushioning the impact of changes in supply and demand upon the wage structure. The central thrust of the section that follows is an analysis of the institutional and economic changes which, a priori, might have influenced the changes in wage inequality.

\subsection{Labour institutions and wage inequality: empirical evidence}

Recent studies have furnished empirical evidence on the significance of the labour institutions as an explanatory variable in variations of wage inequality. In the developed countries, and as a result of the attention recently focused on institutional variables, numerous studies have analysed the effects of the minimum wage, collective bargaining and the role of the trade unions as determinants of the changes in the labour market and, in particular, of the variations in wage inequality. In the United States, for example, where levels of wage inequality increased significantly during the 1980s, various estimates suggest that the erosion of the real minimum wage accounts for between $30 \%$ and $70 \%$ of that increase, depending on the type of methodology used (see Lee, 1999; Fortin and Lemieux, 1997; Dinardo and Lemieux, 1997 and Card and Krueger, 1995). With regard to the role of the unions, and in particular that of collective bargaining, several studies have found that workers who are covered by collective agreements receive higher wages than those who are not. Irrespective of the methodology used, the various studies find that approximately $20 \%$ of the increase in inequality in the United States was attributable to the decline in union activity (see Lewis, 1986; Freeman, 1980 and 1996; Card, 1992; Kahn, 2000 and Dinardo and Lemieux, 1997). In addition, various studies have shown that policies aimed at the decentralization of collective bargaining have resulted in increases in levels of dispersion. In the United States, where negotiations take place on a decentralized basis at company level, and where there are substantial differences between companies, David and Haltiwanger (1991) find that a substantial proportion of wage inequality (48\%) is accounted for by the differences between companies. Blau and Kahn (1996) have found significant evidence that, in the case of the United States, there is a negative correlation between the degree of centralization of collective bargaining and the wage dispersion and wage differential between distribution percentiles 5010. In similar vein, Elliot and Bender (1997), analysing the reforms tending towards greater decentralization in Australia, Sweden and the United Kingdom, find evidence that those reforms resulted in an increase in wage dispersion.

Adopting this approach, it could be shown - and it is this that the present section attempts to do - that in Argentina, beginning in 1976 with the breakdown of the democratic system, there began a series, still continuing today, of different types of state intervention in the labour market, which affected the patterns of wage determination and the traditional institutions of the labour market, and that these were central elements in determining the factor that has the greatest impact on inequality: workers' wages. 


\subsubsection{State intervention, labour regulations and pay in Argentina}

Various theories exist that endeavour to explain wage determinants. Among them, some postulate that the wage level is explicitly dependent on the market and, consequently, on the movements of supply and demand. Thus, the wage is one more relative price within the economy, while labour is a good which is subject to supply and demand, like any other transaction. From another standpoint, which for historical reasons could be considered more appropriate to an analysis of the Argentinian case, it is argued that wage determination has been dictated by a different type of conditioning factor. Frenkel (1986) distinguishes three types of restrictions relating to the fixing of wages. The first type comprises cultural models, habits, conventions and ethical standards. The second relates to the institutions that provide the framework for wage negotiation and the forces that impact on its results. Finally, in the third category, factors such as the political framework, the orientation of the government and public policies come into play.

These mechanisms probably display greater stability in the developed countries, which means that economic factors might assume greater importance. However, as we shall see, in Argentina and in Latin American countries in general, these factors have been central to the process of wage determination. Frenkel (1984), analysing series of real wages in Argentina during the 1970s and 1980s, notes statistically distinguishable phases of "high" and "low" wages, the transitions between which are associated with political changes or changes in the direction of action by the State. Marshall (1995b) identifies four stages between 1976 and 1993 that are differentiated in terms of the institutional system of wage determination.

Table 3 brings together information from various sources and shows the characteristics of each of the phases of wage determination in Argentina between 1980 and 1999, showing the policies implemented in each case and their impact on the labour market.

The period of military rule between 1976 and 1982 was one of the worst in terms of changes in the real wage and wage inequality. Over the whole of that period, real wages fell by $40 \%$ (chart 4 ) while wage inequality increased by $17 \% .19$ Two very specific facts may explain this pattern. First, the priority objective of the military government's economic policy was to reduce the high levels of inflation. To achieve this, instead of devaluation, prices were freed and the rate of exchange was adjusted to inflation, while wages were frozen for a period and only subsequently permitted to move in accordance with the increases in prices (Gerchunoff and Llach, 1998). However, these adjustments, which were determined unilaterally by the State, were always set at lower levels than the recorded rate of inflation. Secondly, an attempt was made to dismantle the trade union apparatus by measures such as the suspension of all union activity, the abolition of negotiations, the revocation of the right to strike and the removal of social work from the unions' sphere of activity. ${ }^{20}$ The aim was to avoid any collectively organized response to the cuts in wages and labour costs. ${ }^{21}$

\footnotetext{
19 In this case, the average of all the computed inequality coefficients has been used.

20 "Social work" should be understood as meaning the activities of those organizations, principally run by the unions, which provide social and health services to workers in a particular sector of activity.

${ }^{21}$ The objective was to avoid any collectively organized response to the proposal to reduce wages and labour costs, an overreaction, since the unions would have had very little room for manoeuvre under a government that adopted a highly restrictive attitude towards all personal rights.
} 
Table 3

Summary of interventions in the labour market

\begin{tabular}{|c|c|c|}
\hline Stage & Policies & Results \\
\hline $1976-82$ & $\begin{array}{l}\text { State fixing of wages and minimum wage freeze. } \\
\text { Companies free to set pay levels. } \\
\text { Suspension of trade union activity and of the right to } \\
\text { strike, abolition of collective bargaining, and } \\
\text { intervention in the social work of the unions. }\end{array}$ & $\begin{array}{l}42 \% \text { fall in the real wage } \\
\text { between } 1976 \text { and } 1978 \text {. } \\
20 \% \text { fall in the real wage } \\
\text { between } 1980 \text { and } 1982 \text {. } \\
17 \% \text { increase in wage } \\
\text { inequality. }\end{array}$ \\
\hline $1985-7$ & $\begin{array}{l}\text { State administration of wages. } \\
\text { Active union intervention. } \\
\text { Wages, interest rates and service charges frozen. Price } \\
\text { control on manufactured goods. }\end{array}$ & $\begin{array}{l}11 \% \text { fall in the real wage. } \\
8 \% \text { increase in wage } \\
\text { inequality. }\end{array}$ \\
\hline 1988-90 & $\begin{array}{l}\text { Collapse of the wage freeze and introduction of a } \\
\text { coordinated system of wage administration } \\
\text { (government, employers and unions). } \\
\text { Reintroduction of collective bargaining in } 1988 \text {. }\end{array}$ & $\begin{array}{l}15 \% \text { fall in the real wage. } \\
5,000 \% \text { increase in the CPI. } \\
8 \% \text { reduction in wage } \\
\text { inequality. }\end{array}$ \\
\hline 1991-3 & $\begin{array}{l}\text { Wage increases made dependent on productivity. } \\
\text { Variable pay subject to performance. } \\
\text { Decentralization of collective bargaining. } \\
\text { Increased flexibility of labour relations and reduction of } \\
\text { labour costs through reductions of employers' } \\
\text { contributions. } \\
\text { More flexible rules on dismissal. }\end{array}$ & $\begin{array}{l}\text { Slight recovery in real wages } \\
\text { during the period of } \\
\text { hyperinflation. } \\
47 \% \text { rise in the rate of } \\
\text { unemployment. } \\
4 \% \text { increase in wage } \\
\text { inequality. }\end{array}$ \\
\hline 1995-9 & $\begin{array}{l}\text { Introduction of apprenticeship contracts involving no } \\
\text { employment relationship for up to } 2 \text { years. } \\
\text { Probationary period of up to } 6 \text { months without } \\
\text { compensation for dismissal and with exemption from } \\
\text { contributions to the pension system. } \\
\text { Abolition of the month's notice of dismissal. } \\
\text { Elimination of employers and employees' } \\
\text { contributions. } \\
\text { New employment system for companies with fewer } \\
\text { than } 40 \text { employees. } \\
\text { Collectively negotiated changes in the rules governing } \\
\text { holidays, Christmas bonuses, mobility, etc. }\end{array}$ & $\begin{array}{l}\text { The unemployment rate } \\
\text { reaches } 20.2 \% \text { in May } 1995 \text {. } \\
1.5 \% \text { fall in the real wage and } \\
20 \% \text { increase in wage } \\
\text { dispersion. } \\
\text { Proportion of wage earners } \\
\text { receiving no social benefits } \\
\text { increases from } 29 \% \text { to } 36 \% \text {. }\end{array}$ \\
\hline
\end{tabular}

Source: Based on Marshall (1995, 1995b, 1997), Cortés (1996), Cortés and Marshall (1999), Beccaria (1996) and various labour legislation.

The second stage comprises the period 1985-7. It was typified by a very hostile attitude by workers towards the State, which continued to administer wages. As a product of the "Austral Plan", a typical incomes policy was introduced, involving controls on prices of manufactured goods, the interest rate, public service charges and wages; it brought about some slight degree of stabilization but this soon ended with a further resurgence of inflation. ${ }^{22}$

22 "Traditional" economic theory holds that income policies can only be effective over short periods, since price controls eventually prove impossible, sector by sector, and tend to cause inefficient disruptions. Even so, such policies have been applied with satisfactory results in some countries of south-east Asia, and even in France. 
The period featured a further downward wage spiral, with a fall of $13 \%$ and an $8 \%$ rise in wage inequality.

Inflationary pressures peaked at the end of the next period, 1988-9, when prices rose by $5,000 \%$. During this period the hostile labour relations continued against a background of heavy pressures on employers, unions and lending banks. This brought about the collapse of the wage freeze and a coordinated system of wage administration which proved incapable of controlling wage increases (Cortés, 1996). Real wages fell sharply, reaching their lowest level of the 1980s during the hyperinflationary process of 1989.23 Similarly, collective labour negotiations were reintroduced at the end of 1988, over ten years after they had been suspended.

The period 1991-3 saw the first series of reforms designed to increase the flexibility of working conditions and reduce labour costs. In 1991, with the introduction of the "Convertibility Plan", a decree was approved whereby wage increases would become dependent on improvements in productivity, subject to the condition that they were not reflected by prices. In turn, wage negotiations were decentralized to sector level, with changes being made to terms of employment and pay systems. In that same year, an Employment Act was passed, the purpose of which was to amend the legislation governing individual and collective relations in order to make it more flexible and, fundamentally, to reduce labour costs. The policies implemented were the reduction of employers' contributions and more flexible regulations on dismissals through the introduction of subsidized fixed-term contracts of employment (for work experience, new activities, in-service training, etc.). ${ }^{24}$ As far as pay is concerned, there was a tendency to adopt pay schemes including variable components subject to explicit performance criteria, such as the payment of conditional bonuses to reward good attendance, an increase in the number of hours worked per day or meeting certain quantified targets in terms of productivity or results (Szretter, 1993). Real wages recovered slightly owing to the stabilization of prices at the time of hyperinflation, basically because monetary stabilization gave rise to an increase in demand via an income effect and a wealth effect caused by the automatic revaluation in dollars of real estate and financial assets (Hidalgo, 1999). Nevertheless, unemployment rose by $47 \%$ and wage inequality by $4 \%$.

The most important institutional reforms began in the final stage (1995-9), by which time the unemployment rate was already in double figures. Subsidized, flexible and shortterm measures were introduced, such as apprenticeship contracts involving no employment relationship for a period of two years. A 50\% reduction in social services contributions was approved and the probationary period was extended to six months, during which employers and employees alike were exempt from contributions to the pension scheme and no compensation was payable in the event of termination of the contract. This meant that the ultimate safeguard attaching to this type of contract, the one-month period of notice of dismissal, was ineffective. ${ }^{25} \mathrm{~A}$ new system was also introduced for undertakings employing fewer than forty people, which shorter periods of notice of dismissal and negotiated changes to the rules governing holidays, Christmas bonuses and internal mobility. The unemployment

23 This was reflected by a reduction in the proportion of the national income made up by wages. The data, which are available for the period up to 1989, show that this proportion fell by $45 \%$ between 1976 and 1989.

24 These arrangements formed part of what can be described as one of the aspects of the policies of flexibilization, in this case the provision of more flexible entry into employment (Feldman, 1995).

${ }^{25}$ Compensation had already been abolished under previous systems. 
rate, which in May 1995 had reached 20.2\%, fell and stabilized at around 15.5\%, while wage inequality increased by $20 \%$ over the period as a whole, with a continuing rise in the numbers of people in unregistered employment and totally unprotected jobs.

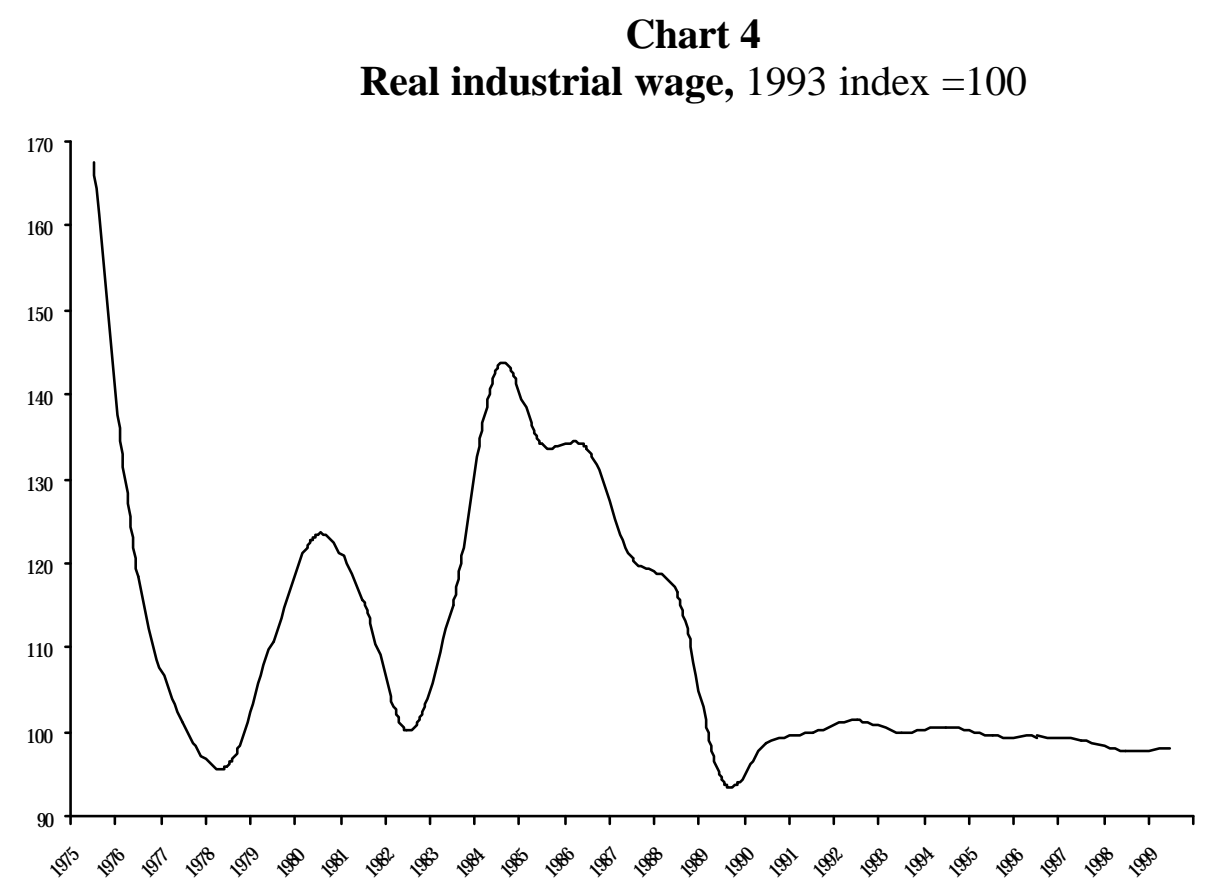

Source: Author's calculations based on ECLAC and Marshall (1995).

The analysis of these stages shows that although it is difficult to identify a consistent pattern underlying the labour policies of the past twenty years, a common feature is the application of restrictions to the labour market. Those restrictions are apparent from the time of the economic policies of the 1980s, typified by the inflationary economic climate and by calculated policies to undermine the labour institutions, weaken social protection and erode fundamental labour rights. Taking due account of the effects of this regulatory activity on the labour market, we will now move on to analyse two specific factors that are regarded by the authorities as significant to an understanding of wage inequality: the minimum wage and labour negotiations.

\subsubsection{The minimum wage}

The minimum wage can be an effective tool for protecting the most vulnerable sectors of the labour market. In terms of its possible impact on inequality, one of the most important characteristics of the minimum wage as an economic policy is the redistributive effect, benefiting workers on low incomes.

According to Freeman (1996) and to Dolado et al. (2000), the minimum wage has at least four characteristics that make it an important tool for redistribution. First, it entails no direct cost to the public sector. Identifying the sectors in which the minimum wage is paid will depend on conditions in the labour and product market in which the workers are employed, but it will never have budgetary consequences such as might result from a system of subsidies. Secondly, the impact on consumers in each income bracket will be neutral, because if the workers on minimum wages produce more low-priced goods, those goods can 
in theory be purchased by consumers in the low-income sectors. However, owing to the fact that those earning the minimum wage work in the services sector (hotels, restaurants, etc.), the high-income sectors will also be paying this minimum price. Thirdly, although the minimum wage produces no effect on the poorest sectors of the population, such as the long-term unemployed or low-income families, it does have significant effects in compressing the lower part of the distribution by increasing the wages most remote from the mean. The final characteristic is probably the most discussed, though the results of the debate are undoubtedly ambiguous: the potential effects of the minimum wage on employment. The assumed impact on employment has been a subject of discussion for the last twenty years or more. If the analysis is based on a competitive economic model, where prices are determined by the free interplay of supply and demand, and we introduce a minimum level below which this wage cannot fall, demand for labour will fall away as a reaction to this "fictitious" price, and the situation will probably be worse than it was before the minimum wage was introduced. For this reason, those workers whose marginal output is valued at below the minimum (lowskilled workers) would join the ranks of the long-term unemployed. If, on the other hand, we do not consider the assumption of perfect competition in the labour market as capable of explaining the real situation, owing to the fact that the real economy is dominated by monopsonic forms, the first model would not be valid for the purposes of explaining the effects on employment. 26 Various empirical studies have considered whether groups exist that are prejudiced by the introduction of the minimum wage, particular attention being paid to low-waged workers and young people between the ages of approximately 15 and 24 . These studies analyse whether the elasticity of demand for workers earning the minimum wage exceeds unity. If that is the case, the minimum wage will reduce the incomes of the lowwaged sectors. Freeman (1996) says that the debate on the effects of the minimum wage in employment is a debate on values in the vicinity of zero, an assertion that appears to be confirmed by the majority of researchers. Among them, Brown et al. (1982) demonstrate that in the case of the United States during the 1970s, the elasticity of employment with regard to the minimum wage was low $(-0.1)$, showing that an increase of $10 \%$ in the minimum wage would reduce employment by no more than $2 \%$. Machin and Manning (1996), analysing the introduction of the minimum wage in the United Kingdom, find that elasticities are negative but close to zero, indicating that the effects of the minimum wage on total employment are almost non-existent.

As far as young people are concerned, the conclusions of the various studies are generally consistent with the hypothesis that the minimum wage causes job losses. Neuman and Wascher (1999), analysing cross-sectional data for 16 developed countries, find that the minimum wage has negative and statistically significant effects on employment rates for young people between the ages of 15 and 24 (elasticity between -0.3 and -0.4 ) and for those between the ages of 15 and 19, where the elasticities are greater (between -0.45 and -0.55 ). Similar conclusions are reached by Dolado et al. (2000), where 7 out of 15 countries analysed have negative and statistically significant elasticities and the remaining 8 have elasticities that are very close to zero, and in some cases even positive. In France, where the minimum wage

\footnotetext{
${ }^{26}$ Not only that, but in a context of high unemployment, it is to be expected that there will not be a high level of competition for labour between undertakings and that they may therefore be more able to influence prices, in the case of the labour market, and on this assumption wages would fall and working conditions would even be affected.
} 
in real terms has remained high over the course of time, Bazen and Skourias (1997) and Fitoussi (1994) find that the minimum wage legislation has had a significant and negative effect on employment among the young and in low-qualified sectors.

\subsubsection{The limits of the minimum wage in Argentina}

The introduction of the salario vital mínimo y móvil (minimum and variable living wage - "SM") dates back to Act No 16459 of 1964, which is still in force, subject to various amendments introduced in 1978. The act defines the SM as the minimum remuneration necessary to provide a worker with sufficient food, decent accommodation, education, clothing, health care, transport and recreation, holidays and social welfare. It provides that "every employee" over the age of 18 shall be entitled to receive payment of not less than the minimum wage. In due course, the National Council for the SM was set up to monitor the SM and readjust it from time to time to allow for possible changes in the price index.

In the present work, two indicators are used to assess the effects of the SM. The first is the "Kaitz index", a standard indicator used in the literature on the minimum wage. It tells us the relationship between the average wage and the minimum wage. The second is the proportion of workers receiving the minimum wage or less than the minimum.

An analysis of changes in the Kaitz index enables us to distinguish at least three periods: 1980-7, 1988-90 and finally 1991-9 (chart 5). The first phase reveals an oscillating pattern, with regular falls caused by the minimum wage breaking away from the average wage, mainly as a result of price movements and because it has become apparent that updates have been insufficient to compensate for the devaluation of the SM. On this point, Sánchez and Giordano (1988) note that, in the period immediately after the Minimum Wage Act was adopted, there were only two updates implemented by the legislative council set up for that purpose; from 1966, however, the government took over from the council and updates became a matter for the exclusive discretion of the government. More recently, in 1988, the power of the council to decide upon increases in the minimum wage was restored. Nevertheless, the minimum wage remained consistently high during this period, at a level even comparable to that existing in some developed countries. 27

The hyperinflationary period definitively showed that the SM was completely defenceless against price increases. Thus, in May 1990, the Kaitz index falls to its lowest level for the series, at a mere 2.16\% of the average wage. In September 1989 and August 1990 updates took place, but these fell far short of the 1,500\% rise in the CPI over that period, and even farther short of the 4,900\% increase in 1989. The effect of this trend was that in May 1990 the minimum wage in constant values was 10 dollars. In the 1990s, when price stability had been achieved, the Kaitz index adopted a more stable pattern and settled at values around $28 \%$.

27 Despite wide fluctuations, the Kaitz index for the 1980s averaged 50\%, a figure comparable with those for countries like Belgium (0.60), the Netherlands (0.55) and Portugal (0.45) and above those for the United States (0.33), Australia (0.35) and Spain (0.35) (see Dolado et al., 2000). 


\section{Chart 5 \\ Minimum wage}

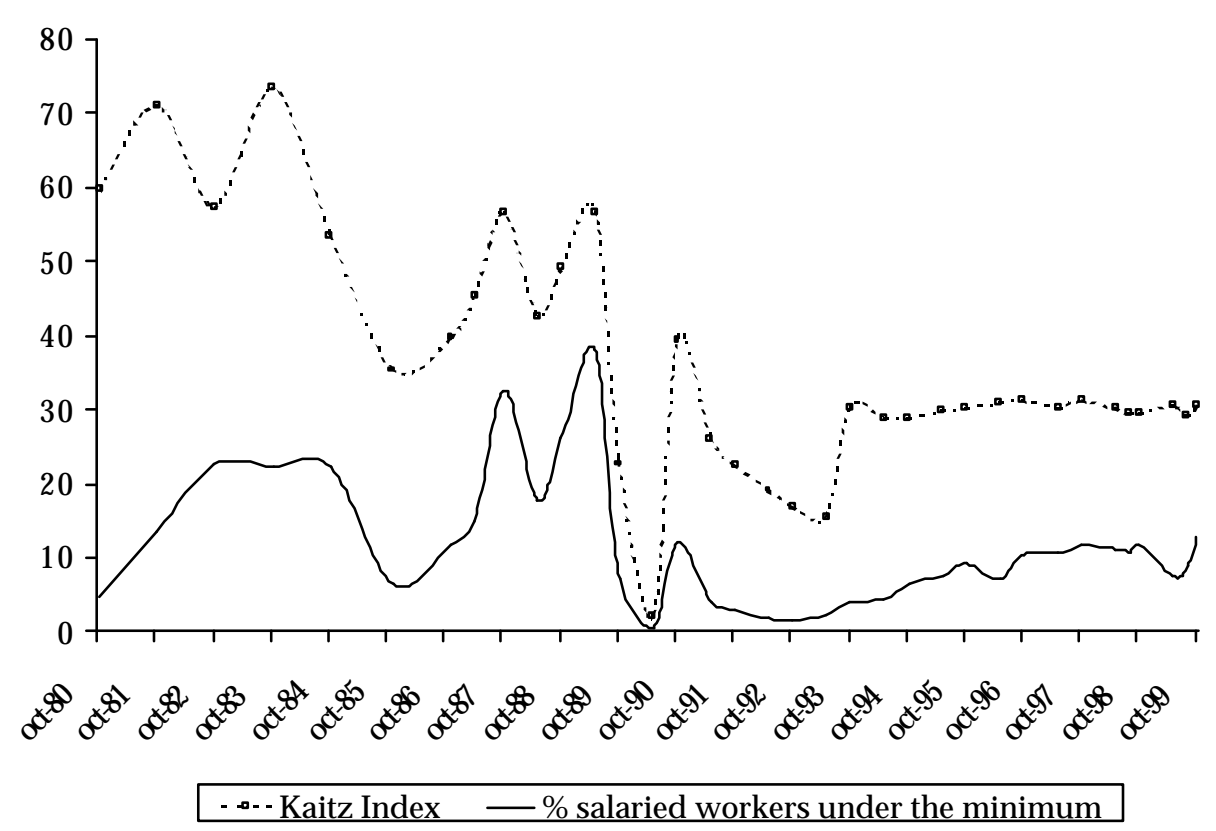

Source: Author's calculations based on EPH, INDEC and Ministry for Economic Affairs, Argentina.

The other important aspect of the minimum wage as a distributive tool is the extent to which it applies. This is influenced by two factors: first, the level fixed by the minimum wage policy, and secondly, the extent to which companies comply with it. It is notable that the percentage of employees receiving wages below the minimum is closely related to the Kaitz index. The reason for this is that, during periods when the minimum wage remains high, as for example during the 1980s, the extent to which companies fail to comply with the rule also increases. When the minimum wage is at a very low level by comparison with the average wage, as in the year 1990, the number of workers below the minimum is zero. The lower the wage levels, the lower the number of unprotected workers, especially since labour demand decisions are unaffected.

The minimum wage in Argentina has been very far from being a redistributive factor serving to reduce inequalities between employees. The reason for this is that there was a significant difference between the ambitious and innovative aspects of the act and an enduring situation of economic deterioration, rising prices and little or no updating. This made the minimum wage a less effective redistributive factor and, consequently, reduced its value as a tool for reducing inequality between workers. ${ }^{28}$ Nor has it really been a minimum, since during the 1980s approximately $20 \%$ of employees over the age of 18 were being paid wages below the minimum, while in the 1990s, although the figure fell to $8 \%$, this resulted not from an increase in numbers receiving the minimum wage but from a substantial reduction in its level. On the other hand, its fluctuations show significant reductions in its purchasing power, owing to the fact that there were very few periods in which it was updated to keep pace with

28 The minimum wage trends have not been so very different from the pattern seen in other Latin American countries. The ILO (1997) notes that, in the region as a whole, the purchasing power of the minimum wage fell as a result of accelerating inflation, the weakening of the unions and the adoption of adjustment and stabilization policies that abandoned the minimum wage as an instrument of policy. 
rising prices, as it should have been under existing legislation. Nor can it be described as a living wage, since, when the value of the minimum wage falls below $15 \%$ or $20 \%$ of the average wage, it becomes insufficient to pay for the "basic basket" of food. Nevertheless, we agree with Freeman (1996) that, although a minimum wage is not a panacea, especially among the poorer sectors of the population, it is still an important tool for improving the welfare of workers on low incomes and restricting the increases in wage inequality, a hypothesis we propose to substantiate in the empirical analysis.

\subsubsection{Collective bargaining}

After 1976, with the breakdown of the democratic system, the collective bargaining system was abandoned, not to be reintroduced - with some modifications - until 1988. This fact is not inconsistent with the history of collective bargaining, the use of which has been highly spasmodic over the course of time, with alternating periods of normality and abolition, and with a high point in 1975, the year in which the most agreements were recorded in each sector of activity.

As can be seen in table 4, the principal form of negotiation until the late 1980s focused on individual sectors of activity, agreements being concluded between the national unions and the employers' associations. Negotiations of this type accounted for between $70 \%$ and $80 \%$ of the agreements recorded at those times. 29

Table 4

Current collective labour agreements

\begin{tabular}{l|c|c|c|c|c|c|c|c}
\hline Level & 1975 & $\%$ & $1988-90$ & $\%$ & $1991-99$ & $\%$ & Total & $\%$ \\
\hline Sector & 304 & 69.1 & 118 & 79.7 & 136 & 35.1 & 558 & 57.2 \\
\hline Company & 136 & 30.9 & 30 & 20.3 & 252 & 64.9 & 418 & 42.8 \\
\hline Total & 440 & 100.0 & 148 & 100.0 & 388 & 100.0 & 976 & 100.0 \\
\hline
\end{tabular}

Source: Cappellety et al. (2000), based on Coordinación de Investigaciones y Análisis Laborales [Department of Coordination of Labour Studies and Analyses], Secretaría de Trabajo [Labour Secretariat], Ministry of Labour and Social Security, Argentina.

The early 1990s saw the start of a trend towards growing decentralization of collective bargaining to company level. Over the period 1991-9, of the total number of agreements recorded, only $35 \%$ were at sector level, the remaining $65 \%$ being company agreements. 30

The restrictions on job security, and especially the decentralization of collective negotiations, were introduced with the idea of reducing costs, helping to maintain price stability, keeping wage dispersion in line with differences in productivity and improving

29 This "historic" structure, centred on intermediate levels, had since the beginning displayed a high level of stability, reinforced by the traditional reluctance of the unions to accept any form of decentralization of levels of negotiation. This continuing stability was further reinforced by the mechanism known as ultraactividad (literally "ultra-activity"), whereby the effects of an agreement continued even after it had expired, enabling the unions to preserve the traditional levels of negotiation and resist demand from the employers for renegotiation (Goldin, 1999).

30 Although the average figures show that, of the total number of agreements signed between 1991 and 1999 , 65\% were at company level, the annual data show that the percentage of all agreements accounted for by those concluded at company level rose from 19\% to 80\% between 1990 and 1998 . 
external competitiveness (Marshall, 1997). For this reason, in 1991, 1993, 1995 and 1998, various legislative measures were approved with a view to achieving those results. ${ }^{31}$ It follows from this that, among the collective agreements concluded between 1991 and 1999, many contain clauses that are relatively unfavourable to the interests of the workers.

Table 5 shows the most common clauses included in the majority of company-level agreements over the period 1991-9. The most common rules relate to topics such as the annual distribution of holiday (22\%), reassignment of functions (20\%), pay (23\%), subsidized forms (30\%), multitasking (30\%), allocation of working hours $(35 \%)$ and regulation of union activities (15\%). Many of these "innovative" concepts masked the real content of the agreements. As stated by Novick (2000), the heading of "productivity" was used for negotiations on flexibility, both external (authorizing subsidized forms of working and mechanisms for the temporary contracting of staff) and internal (mobility and multitasking), and flexibility of pay (negotiation of a variable component of the wage) and of working hours (flexitime, annual or monthly calculation, credit and debit systems, etc.). Conversely, it is also noticeable that the least common clauses in these agreements were those relating to quality of employment (health and safety at work and workers' use of protective equipment), while there were no clauses at all on subjects such as protection of employment. What is demonstrated by the decentralization of negotiations to company level is that the type of clauses favoured are those that give rise to changes, often in terms of wages, in any direction, which gives us the clue to a possible impact on wage inequality. In other words, the result of the greater heterogeneity in wage variations creates incentives within companies to increase flexibility in response, for example, to adverse market conditions. Similarly, the decentralized forms, as argued by Blau and Kahn (1996), would appear to have a greater impact on the lower part of the distribution, significantly increasing wage dispersion.

The sectors in which the majority of these agreements were concluded were large and medium-sized enterprises (in the automotive, mechanical engineering, automotive parts, petrochemical and other industries) and those that had benefited from deregulation and privatization (airlines, mail carriers, utilities, railways, communications, etc.). One of the most striking examples of this process, perhaps encapsulating the new role of the employers and the disappearance of the State as a mediator in disputes, occurred in the case of the car-making companies. The car makers who opened their factories in the early 1990s are imposing their collective agreements without reference to the workforce - in other words without having made the investment in plant and equipment and without having contracted any staff. In turn, employers in many of these undertakings, when hiring staff, require them to be young and previously unconnected with trade unions (Battistini, 1999).

\footnotetext{
31 The acts and decrees promulgated were as follows: Ley Nacional de Empleo [National Employment Act] No 24013/91; Decreto sobre desregulación [Deregulation Decree] No 2.284/91; Decreto sobre negociaciones colectivas de trabajo [Decree on Collective Labour Negotiations] No 447/93; Modificaciones del Régimen de Contrato de Trabajo [Amendments to the Contract of Employment System] No 24465/95; Ley Regulación de Pequeñas y Medianas Empresas [Small and Medium-Sized Enterprises (Regulation) Act] No 24.467/95; Ley de Reforma Laboral [Labour Reform Act] No 25.013/98.
} 
Table 5

Most frequent clauses in collective labour agreements

\begin{tabular}{l|c|c}
\hline \multicolumn{1}{c|}{ Most frequent clauses } & $\begin{array}{c}\text { No of agreements } \\
\text { containing those clauses }\end{array}$ & $\begin{array}{c}\text { \% of total } \\
\text { agreements }\end{array}$ \\
\hline Authorization of subsidized forms of contract & 484 & 30.2 \\
\hline Mobility or multitasking & 478 & 29.8 \\
\hline Variable pay components & 367 & 23.0 \\
\hline Reallocation of functions & 324 & 20.2 \\
\hline Annual distribution of holiday & 355 & 22.1 \\
\hline Regulation of union activities & 239 & 14.9 \\
\hline Allocation of working hours & 571 & 35.6 \\
\hline Dispute resolution mechanisms & 363 & 22.6 \\
\hline Training & 369 & 23.0 \\
\hline Works health and safety committee & 137 & 8.5 \\
\hline Use of personal protective equipment & 197 & 12.3 \\
\hline
\end{tabular}

Source: Cappellety et al. (2000), based on Coordinación de Investigaciones y Análisis Laborales, Secretaría de Trabajo, Ministry of Labour and Social Security, Argentina.

This new dynamic in collective agreements reflects a transformation in relations between the State and the unions. From the standpoint of the State, the way was open to make "productive" investments without experiencing the consequences in terms of labour relations and social conditions of the new "negotiated" labour rules, a break with the Peronist political tradition of government, under which the State functioned as the guarantor of union rights. Moreover, the changes taking place in various economic sectors, especially the job losses in those where the unions were more strongly represented, such as industry and the public sector, appeared to have limited the power of the unions. ${ }^{32}$ This would appear to verify the hypothesis advanced by Hyman (1999), when he stated that the traditional core representing union activity had weakened and had polarized towards the extremes, where union activity was much more complex; in other words, those with professional or technical skills who may feel confident of their individual capacity to survive in the labour market coexist with those who have no such resources but whose very vulnerability makes effective collective organization and action difficult to contemplate.

The connection between the changes in the labour regulations - changes in collective bargaining, in this case - and the increases in wage inequality is not easy to verify empirically, owing to the lack of statistics to systematize it. ${ }^{33}$ Nevertheless, and even though there is no conclusive proof, the increase in insecure and unregistered employment in the formal sector, and the increase in informal working, as the labour market reforms were implemented provide us with an indication that the connection may at least be suspected of being a causal one. Not only that, but the connection between labour regulations and increasing wage inequality is strengthened by the considerable statistical significance which, as we shall find in the econometric models, can be identified in variables such as insecure and informal employment, which are independent of wage inequality.

32 ILO (1997) estimates for Argentina indicate that the number of union members, as a percentage of the total workforce, which had been $67.4 \%$ in 1986 , fell to $38.7 \%$ by 1995 , representing a decline of $42.6 \%$.

33 The econometric models incorporate, as an approximation, the institutional effects on wages. 


\subsection{Economic factors and wage inequality}

The conditions of supply and demand in the labour market have formed part of the central focus of analysis in studies endeavouring to explain the trend of wage inequality. In the case of the United States, in particular, there have been substantial increases in demand for highly educated workers and in returns to education (see Bound and Johnson, 1992 and Katz and Murphy, 1992). Attempts to explain changes in demand have generally focused on those generated by commercial openness and, albeit to a lesser extent, technological change (see Goux and Maurin, 2000; Forbes, 2000; Cornia, 1999; Galiani and Sanguinetti, 2000 and Kanbur and Lusting, 1999). On the supply side, the increase in the size of the workforce, especially in the number of women, has been the factor most emphasized by researchers (see Tzannatos, 1999; MacPhail, 2000; Topel, 1997; Juhn and Kim, 1995; Fortin and Lemieux, 1997).

In this section, we centre our analysis on the changes in labour supply and demand and their possible effects on wage inequality. A second part, continuing the examination of economic factors, analyses changes in employment, the productivity of labour and their relationship to the economic cycle. Owing to the fact that one of the fundamental problems of the labour market has been its lack of dynamism in the creation of jobs, it is of interest to analyse the various production cycles and the responses of employment (elasticities), principally during the periods of adjustment, where expanding sectors would appear not to have offset the losses of jobs in the declining sectors.

\subsubsection{Changes in returns to education: the demand for educated workers}

The demand for more highly educated workers has increased over the years, especially during the 1990s. This is reflected by an increase in returns to education, especially among those with university education. In the case of Argentina, the changes in the make-up of employment in terms of level of education have been substantial. There has been a significant increase in the number of highly educated employees, a trend that has been less marked among those of average education and negative in the case of low-qualified workers.

As is apparent from table 6, there has been a structural change in the workforce in terms of educational level. Workers with low levels of education have been driven out of employment, and this has been offset, in particular, by an increase in the number of workers who have completed 13 or 17 years of education. Thus, the average increase between the two decades for highly educated employees was over $40 \%$, while at the other end of the scale, among employees with 7 years' education or less, the fall was $23 \%$.

\section{Table 6}

\section{Educational level of employees in GBA}

\begin{tabular}{l|c|c|c}
\hline & 1980s average & 1990s average & $(\%)$ \\
\hline Employees with up to 7 years' education & 47.4 & 36.4 & -23.3 \\
\hline Employees with between 8 and 12 years' education & 35.2 & 39.0 & 10.7 \\
\hline Employees with between 13 and 17 years' education & 17.4 & 24.6 & 41.6 \\
\hline Total & 100 & 100 & \\
\hline
\end{tabular}

Source: author's calculations based on EPH, INDEC. 
The differences in returns to education have also been reflected by a rise in wage differentials by number of years' schooling in the past two decades. Chart 6 shows the average wage ratios between employees who have completed their university studies and those who have completed secondary and primary education, in other words 17 years' as against, respectively, 12 and 7 years' education. When we consider the wage ratio between complete university and complete secondary education, the differentials are around $80 \%$ for the 1980 s and $108 \%$ in the 1990s. Thus university-educated employees earn approximately $100 \%$ more than those with a secondary school qualification. If the comparison is based on those who have only completed primary education, the differentials are very high: in the 1980 s they were around $180 \%$ while in the 1990 s they were close to $200 \%$.

\section{Chart 6}

\section{Wage differentials by educational level,. GBA}

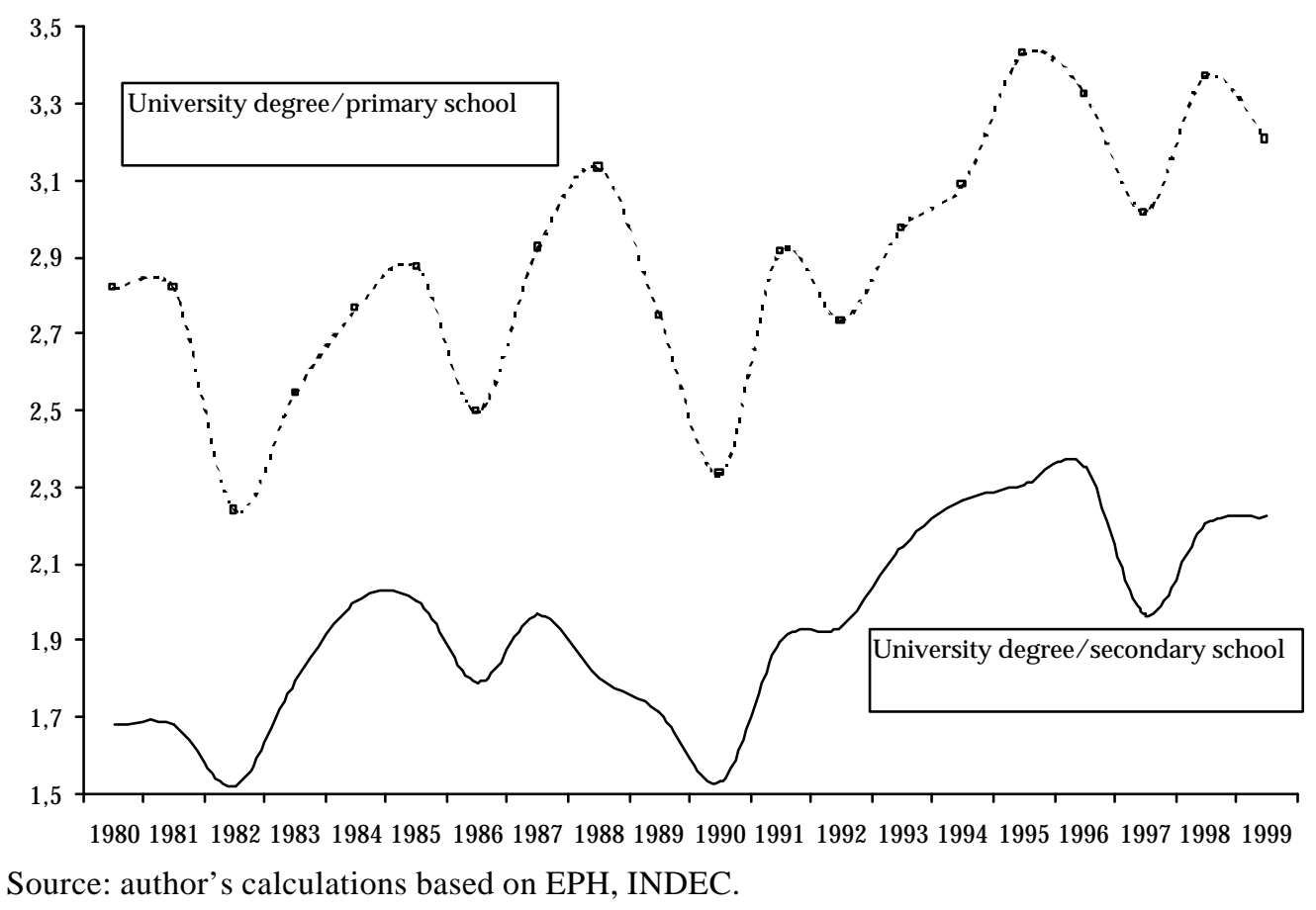

Among the hypotheses most commonly used to explain this process, commercial openness has probably played a significant part. Galiani and Sanguinetti (2000) find evidence to suggest that the relationship between open markets and inequality has existed in Argentina, in particular, since the late 1980s, when the earnings of university graduates rose as a reflection of the implementation of commercial openness.

Argentina would not fit precisely into the mould of those countries where openness has caused an increase in wage dispersion (those that export skill-intensive products and import low-skill goods), nor has it been typified by a lowering of international barriers to trade. Nevertheless, in the late 1980s, and in the context of the economic reforms and the development of Mercosur, a trend towards greater commercial openness began, based on a reduction in duties and protectionist measures. The policy of openness underwent a profound change from April 1991, when a three-tier tariff structure was introduced: $22 \%$ on finished 
goods, $11 \%$ on intermediate goods and $0 \%$ on capital goods not produced within the country. Over the course of time, these rates were gradually modified towards greater commercial openness. 34

As a result of this process, a substantial increase in trade flows took place between 1990 and 1998 . Imports rose by $612 \%$, exports by $94 \%$, and the sum of the two variables by $245 \%$ (chart 7). Nevertheless, and simultaneously with this process, total employment and especially waged employment began to decline significantly in manufacturing industry, owing to the fact that this sector began to shed jobs. The process of economic opening, which developed a powerful impetus in the late 1980s, affected industry and gave rise to a more and more significant process of deindustrialization. 35 The consistently negative trade balances and the slow pace of employment absorption by industry were factors that exerted a greater effect as time went on. This brought radical changes in the employed workforce structure and in the composition of demand, propitious to skilled labour together with high premiums on education.

Chart 7

\section{Exports and imports, Argentina, 1980-99}

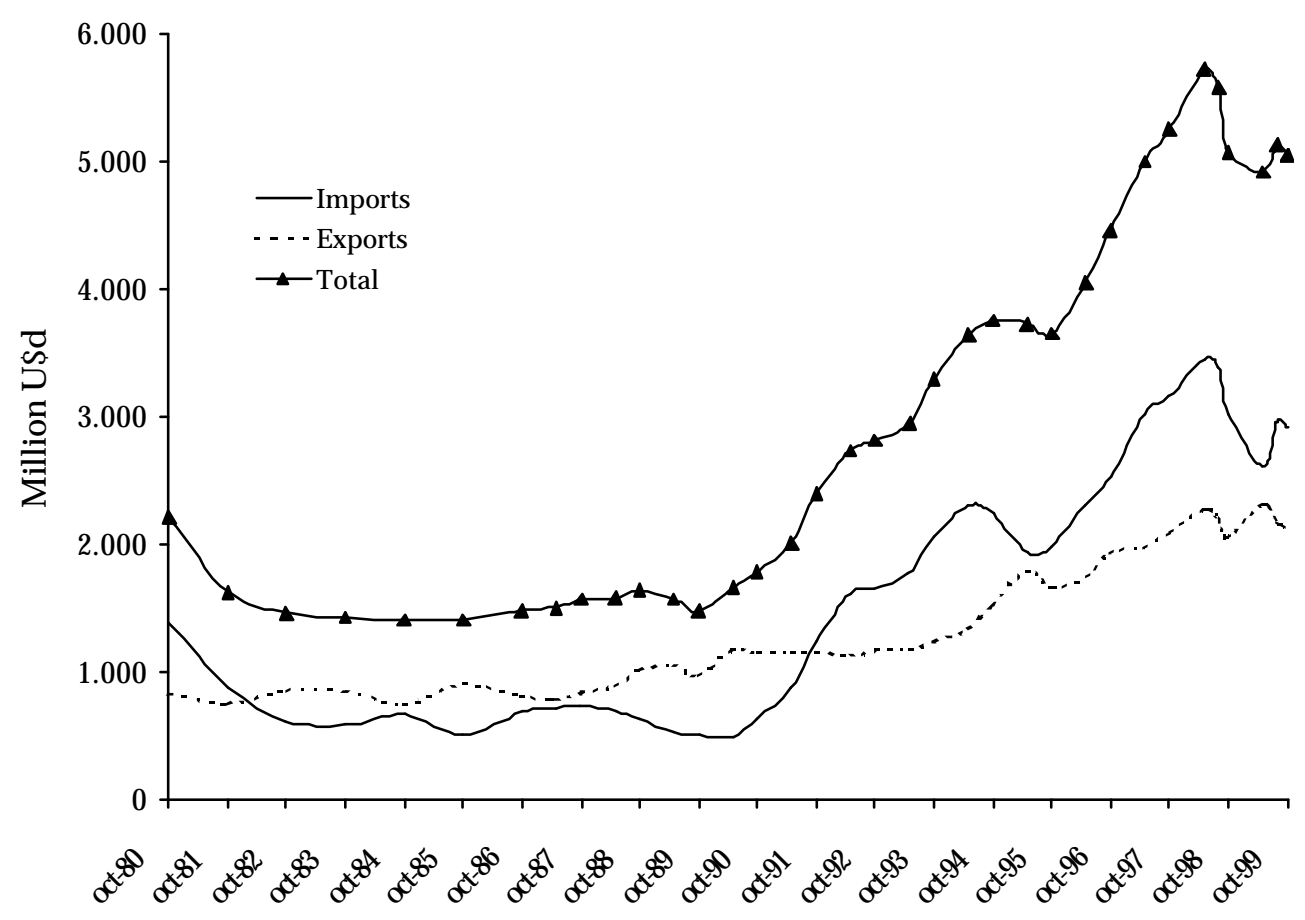

Source: author's calculations based on Ministry for Economic Affairs, Argentina.

\footnotetext{
34 The most important stimulus came from the handling of tariff policy. According to data from the Latin American Economic Studies Foundation, FIEL, the average tariff for the economy fell from 29\% to $11 \%$ over the period $1988-95$.

35 Nor should it be forgotten that the process of deindustrialization and falling employment can be attributed to other, more global factors. During the past 25 years, industrial employment has declined in the United States, Europe and Japan. Rowthorn and Ramaswamy (1997) find that in the 23 most developed countries, industrial employment as a percentage of the total fell from $28 \%$ to $18 \%$ between 1970 and 1994. They identified the causes as being that the increase in productivity was greater in manufacturing than in the services sector.
} 
The fall in the share of waged employment in manufacturing industry was substantial. At the end of the 1970s it represented $40 \%$ of the total, whereas twenty years later the figure was only $20 \%$ (table 7 ). This change went hand in hand with a reorientation of labour demand towards the services, partly to trade but also to other branches of activity (civil service, transport and communications). As analysed in the empirical section, there is no ambiguity about the negative effects of the influence of openness on inequality. The increase in exports had no significant effect on employment, and its low dynamism did nothing to change the downward trend of employment in manufacturing.

Table 7

Employees: percentage distribution by sector of activity, $G B A$

\begin{tabular}{l|c|c|c|c|c|c}
\hline & Industry & Services & Trade & Construction & Others & Total \\
\hline $1974-9$ & 41.3 & 28.0 & 11.6 & 5.1 & 14.0 & 100.0 \\
\hline $1980-4$ & 31.6 & 32.8 & 13.8 & 5.6 & 16.2 & 100.0 \\
\hline $1985-9$ & 29.8 & 33.4 & 13.7 & 4.5 & 18.6 & 100.0 \\
\hline $1990-4$ & 27.0 & 35.2 & 15.5 & 4.1 & 18.2 & 100.0 \\
\hline $1995-9$ & 20.9 & 38.2 & 14.0 & 5.0 & 22.0 & 100.0 \\
\hline
\end{tabular}

Source: author's calculations based on EPH, INDEC.

\subsubsection{Increase in labour supply}

Participation in economic activity by the active population, and especially by the female population, in the labour market is another of the variables analysed, inter alia, to explain the increase in open unemployment. 36 Variations in the incomes of heads of households, changes in the purchasing power of wages and the levelling of educational standards between men and women are the key factors that have been cited to explain the changes on the labour supply side.

In the 1980s, total participation of the population in the labour market expanded very slowly. ${ }^{37}$ During this period, the total activity rate increased by some $4 \%$ : there was no change in the rate among men, whereas the activity rate among women rose by $14 \%$, for the most part from 1983 onwards. This fact has been very clearly documented, and forms part of a global trend: since the 1960s, women have been increasingly involved in the labour market and the educational system. According to ILO data, between 1960 and 1990 male participation rates worldwide increased at an annual rate of $1.9 \%$, whereas the female rate of increase was almost double that at $3.5 \%$ per year.

Cortés (1996b) contended that in the 1980s one of the main characteristics of women entering the labour market was that they came from low-income homes. Similarly, over the course of the decade, a slight upward trend is apparent in activity rates for homes where the income received by the (employed) head of the household was in the bottom $40 \%$ of the wage distribution. On the other hand, the change in the fabric of the economy, from industry to services, resulted in an increase in unemployment among heads of households together with

\footnotetext{
36 See, inter alios, Llach (1998) and Pessino (1996).

37 The total activity rate remained stable at around $40 \%$. This stability can be explained by a substitution effect in response to the sharp fall in pay and the discouragement resulting from the weakening of formal job creation (Altimir and Beccaria, 1999).
} 
an increase in female participation resulting from the growth of the services sector. In other words, what typifies the increase in female participation in the labour market is the desire for earnings to supplement those of the head of the household when the latter is unemployed or his income has suffered a sharp deterioration, combined with a change in the composition of economic activities.

In the 1990s, labour participation rates continued to follow the upward trend apparent in the 1980s, with a particular emphasis on the female rate, especially among women between 35 and 64 years of age, in most cases wives continuing to enter the labour market to supplement the family income. 38

\subsubsection{Labour supply and wage inequality}

The question we pose here is this: has the increase in the number of women willing to work had an impact on wage inequality? To answer that question, we need to pursue two lines of investigation that are touched upon briefly in this section. The first assumption, analysed by, among others, Topel (1997) and Juhn and Kim (1995), suggests that women compete in the labour market with low-waged, low-skilled men and increase inequality, especially among men, by a process of substitution. Various studies would appear to confirm this hypothesis. Fortin and Lemieux (1997) find that $17 \%$ of the increase in wage inequality among men in the United States can be accounted for by the relative improvements in women's wages. The second alternative to be considered is that a rise in the supply of female labour may increase total wage inequality if inequality among women is greater than inequality among men.

The first line of inquiry assumes that women, entering the labour market with high educational qualifications, are replacing low-qualified workers and as well as being paid a lower wage are increasing wage inequality. The characteristics of labour market integration by sex, educational level and wage level would appear to confirm that some form of substitution does exist. It is notable that, among the total of employed women in the labour market, the greatest increase is to be found in the average- and high-waged sectors, with educational qualifications higher than secondary school leaving (table 8). In wage terms, there would appear to be a movement of women from the average- and high-waged sectors to positions previously occupied by men with particularly low wages. The reason for the change in the composition of the workforce by sexes - although it may be influenced by the decline of manufacturing and the rise of the services sector, in addition to the cultural reasons prompting the increase in female participation - is characterized by the need for women to earn an income to supplement that of the man. The group of men forming the middle $60 \%$ of the wage distribution has probably suffered most in labour and socioeconomic terms, giving rise to what some authors call the "new poor". This concept, as expressed by Minujin and

\footnotetext{
38 Nevertheless, the official line has been to try to explain this process with various arguments whose sole purpose was to explain the poor performance of the labour market. In other words, the increase in supply is explained not by low pay, the fall in the real value of pensions, deteriorating working conditions or the increase in unemployment (especially among men); to the contrary, the good performance of the economy has resulted in people entering the labour market. Rabinovich (1999) summarizes these arguments, which we can classify under three headings: demographic reasons, an optimistic workforce and increased pay. In other words, the rise in the birth rate during the 1970s and improved income opportunities available in the market have resulted in an increase in the opportunity cost of staying out of gainful employment; finally, the possibility of obtaining a more highly paid job has meant that individuals who previously refrained from job seeking have joined in.
} 
Kesler (1995), takes account of the impoverishment of a substantial proportion of the middle classes, who, as a result of the various economic, political and social crises, are seeing their incomes decline to the point where they are below the poverty line. This concept is closely linked to wage dispersion, since, as the authors state, although the losses were distributed across all income bands, not all those within each group lost equally, so that the new poor are made up of the losers in each occupational group. ${ }^{39}$

On the other hand, considering the employment structure by educational level, we can see that women have increased their participation in the highly skilled sectors, and that this increase has been substantial and sustained among those who have completed secondary and university education, where it amounts to $150 \%$. Although we do not know the elasticity of substitution between the groups, since this would require a different type of analysis, it is clearly apparent that in both cases there has been a decline in the poorly educated sector that is consistent with the hypothesis of an increase in demand for qualifications and greater participation by employees of both sexes (especially women) who have completed secondary and university education.

Table 8

Distribution of male and female employees by wage and educational levels

\begin{tabular}{|c|c|c|c|c|c|c|c|}
\hline Wages & Year & Men & Women & Education & Year & Men & Women \\
\hline \multirow{4}{*}{ Poorest $20 \%$} & 1980 & 9.4 & $\overline{11.1}$ & \multirow{4}{*}{ Primary } & 1980 & 39.3 & 15.1 \\
\hline & 1990 & 10.2 & $\overline{11.1}$ & & 1990 & 30.2 & $\overline{12.3}$ \\
\hline & 1999 & 6.7 & 10.7 & & 1999 & 20.6 & $\overline{10.0}$ \\
\hline & $99 / 80$ & -28.7 & -3.8 & & 99/80 & -47.7 & -34.0 \\
\hline \multirow{4}{*}{ Intermediate $60 \%$} & 1980 & 40.9 & 19.2 & \multirow{4}{*}{ Secondary } & 1980 & 20.1 & 12.3 \\
\hline & 1990 & 38.5 & 19.4 & & 1990 & 23.4 & 13.6 \\
\hline & 1999 & 37.4 & $\overline{25.1}$ & & 1999 & 24.7 & $\overline{15.9}$ \\
\hline & 99/80 & -8.4 & $\overline{30.8}$ & & 99/80 & 22.8 & $\overline{29.5}$ \\
\hline \multirow{4}{*}{ Richest 20\% } & 1980 & 15.7 & 3.8 & \multirow{4}{*}{ University } & 1980 & 6.5 & 6.6 \\
\hline & 1990 & 14.7 & $\overline{6.1}$ & & 1990 & 9.8 & $\overline{10.6}$ \\
\hline & 1999 & 13.5 & $\overline{6.6}$ & & 1999 & 12.4 & 16.4 \\
\hline & 99/80 & -14.0 & 75.9 & & 99/80 & 89.4 & 150.0 \\
\hline
\end{tabular}

Source: author's calculations based on EPH, INDEC.

The substitution effect could also be apparent if there were to be a slight narrowing of the wage gap between men and women. In other words, if it is assumed that men and women have relatively similar characteristics in the labour market, and that a degree of substitution does in theory take place in the labour market, the increase in the rate of female participation would have a similar influence on the wages of men and women, or at least would not result in the widening of the wage gap between the sexes. As can be seen in table 9, the wage gap between men and women has remained fairly stable, narrowing slightly during the late 1980s but then returning to around $74 \%$ in the 1990s. If there were no substitution between men and

\footnotetext{
39 Owing to the fact that we are referring to a population group that formed part of the middle-income and middle-to-low-income sectors, Salama and Valier (1996) use the phrase "decline in living standards". In other words, heterogeneity is what characterizes the new poor, but in many cases we are talking about individuals with substantial social and cultural capital who are experiencing a change in status, cutting back on consumption and treading a thin line very close to marginalization.
} 
women in the labour market, the wage gap would have broadened as a result of a deterioration in women's wages, whereas what has in fact happened is precisely the reverse.

Table 9

Wage gap between men and women, in \%

\begin{tabular}{c|c|c|c|c}
\hline $1980-3$ & $1984--7$ & $1988-91$ & $1992-5$ & $1996-9$ \\
\hline 0.717 & 0.693 & 0.717 & 0.732 & 0.758 \\
\hline
\end{tabular}

Source: author's calculations based on EPH, INDEC.

Similarly, the increased representation of women in the workforce, and their greater participation in higher education, disproves the belief that women are relatively unskilled, though in practice wage discrimination between men and women is a matter of common knowledge and might even influence total wage inequality levels. Although women are increasingly well educated, and exerting more and more pressure in the labour market, they are required to offer better educational credentials than men in order to do the same job, and for a lower wage. In a structural context such as that described, where the coexistence of such phenomena as shortage of employment opportunities and higher school enrolment at every level of education has given rise to what has been called the "queue effect", 40 the stigmatization of women is very much a dominant feature of the working world. Being a woman, and having the other personal qualities associated with the sex, is still an important factor in determining the employability options, as is demonstrated by the fact that, for a given job, women are expected to have higher educational qualifications than men and in many cases are paid less.

The second hypothesis would appear, a priori, to have some impact on overall inequality. Inequality among female employees, over the period 1980-99, was significantly higher than among men (chart 8). This trend would appear to have increased from 1992 onwards, with a significant growth of the highest percentiles of distribution and the wage differentials between the 5th and 1st quintiles tending to be higher than in the case of men. ${ }^{41}$ This is explained by the fact that, as mentioned earlier, the sustained increase in the representation of women in the long term is typified by the entry into the labour market of women with high educational qualifications and medium to high socioeconomic levels. In other words, although the wage gap between men and women remains high, there are also high levels of wage inequality among women themselves.

\footnotetext{
40 Carnoy (1993) says that educational qualifications may, in certain contexts, generate what he called the "queue effect". When a lack of employment opportunities coexists with the availability of skilled labour, it may happen that those who have put in more years at school displace those with less formal education from the leading places in the job queues, even when the jobs concerned require only low levels of skill.

41 These findings are consistent with those reached by Richardson (1997) and MacPhail (2000) in the case of Canada.
} 


\section{Chart 8}

Wage inequality between men and women: Atkinson coefficient (2.5) - Index 1980=100

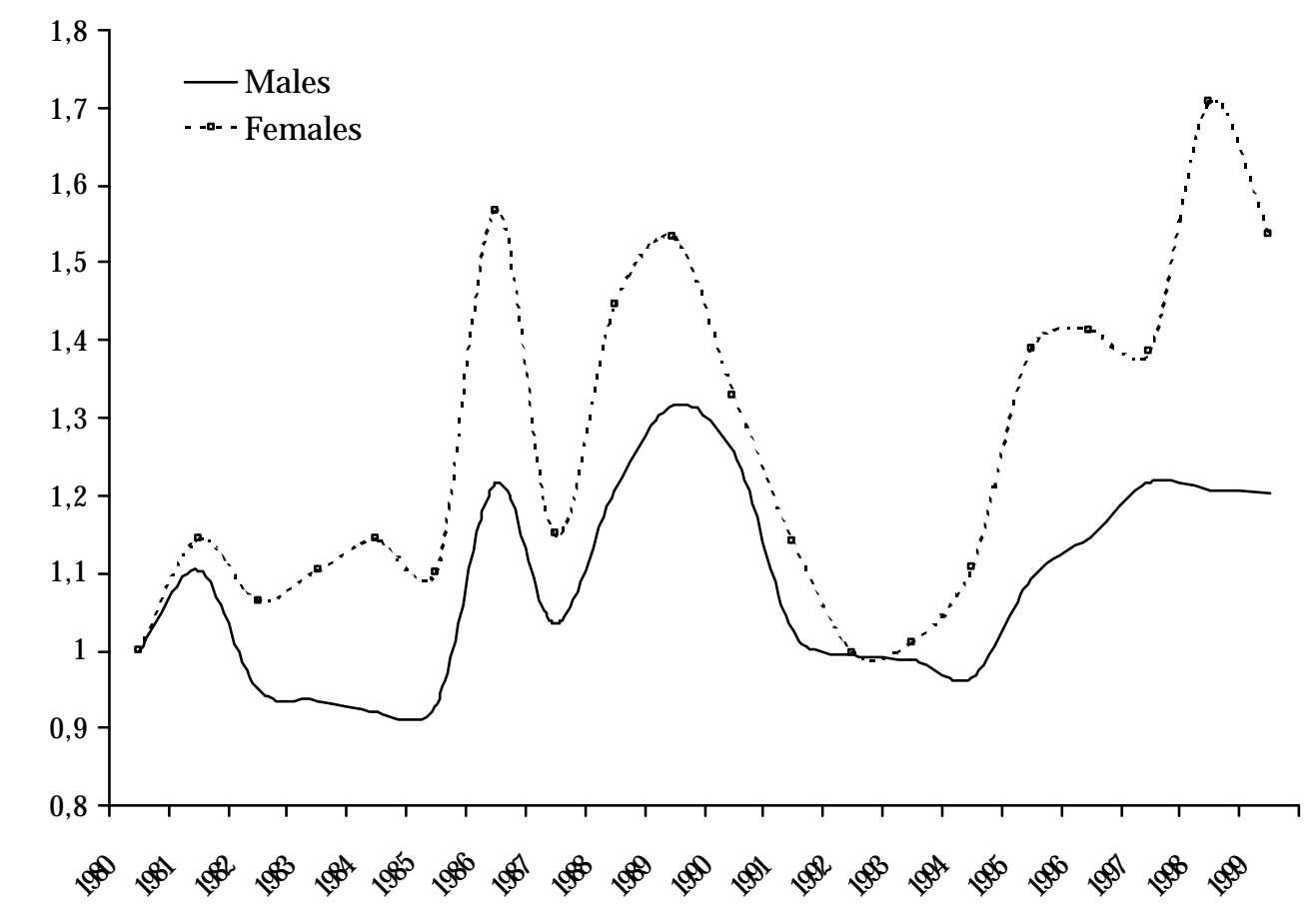

Source: author's calculations based on EPH, INDEC.

\subsubsection{Employment, economic cycle and productivity of labour}

\subsubsection{The response of employment to changes in the economic cycle}

The Argentinian economy in the 1980s was characterized by an unsatisfactory macroeconomic course over almost the entire period. Some of the roots of the labour problems that followed during the 1990s can probably be traced back to this decade. The unemployment rate in the late 1980 s was in the vicinity of $7 \%$, and underemployment rose to some $70 \%$, while on the employment side there was a slight increase of $16 \%$ between the beginning and end of the period. Nevertheless, the spread of unemployment and the slight rise in employment are highly positive data if we bear in mind that GDP fell by approximately $10 \%$ in the course of the $1980 \mathrm{~s} .42$

In the 1990s, it is much more difficult to see a uniform pattern linking changes in output and changes in employment. The reason for this is that, for example, in 1990 output fell and employment rose, between 1991 and 1993 the economy grew by some 10\% each year while employment rose by only $2 \%$, in 1994 output grew but employment fell, both variables declined as a result of the Mexican crisis, and from 1996 onwards there is a positive correlation between the two variables. Nevertheless, if we focus particularly on the period of economic expansion from 1991 to 1994, the weaknesses of the positive correlation between economic growth and employment become obvious. Over the cycle of expansion in 1990-4,

42 In real terms, production in 1990 was at virtually the same level as in 1975, whereas per capita GDP fell by some $20 \%$ over the same period. 
GDP rose by $35 \%$, employment by $8 \%$ and unemployment by $105 \%$, reaching the all-time peak of $18.8 \%$ in May 1995.

A good yardstick for understanding the variations in employment over the phases of the economic cycle is by calculating the elasticity of employment in response to changes in output 43 (table 10). In the 1980s, the elasticity of employment with respect to output changes was negative, being in the region of -1.6. In the 1990s, during the period of expansion, the average elasticity was 0.21 , indicating that a rise of $10 \%$ in GDP would generate a $2 \%$ rise in employment. Focusing particularly on this trend, we can see that at the start of the cycle of expansion, elasticity begins to fall, actually becoming negative in 1994, the last year of the period of expansion. It is only from 1995-6 that it begins to recover in line with the rise in output. Thus, over the period 1991-4, output increased at an annual rate that did not even absorb the increase in the economically active population.

Table 10

Trends of output and urban employment

\begin{tabular}{c|c|c|c}
\hline & $\begin{array}{c}\text { Employment } \\
\text { (rise in \%) }\end{array}$ & $\begin{array}{c}\text { GDPmp } \\
\text { (rise in \%) }\end{array}$ & $\begin{array}{c}\text { Employment-output } \\
\text { elasticity }\end{array}$ \\
\hline $1980-90$ & 16.40 & -10.02 & -1.61 \\
\hline $1991-4$ & 8.10 & 35.60 & 0.23 \\
\hline $1995-8$ & 8.52 & 13.60 & 0.63 \\
\hline
\end{tabular}

Source: author's calculations based on INDEC and ECLAC.

Many different explanations have been offered for the response of employment to changes in output. In general, it has always been argued that the strict regulation of the labour market caused employment not to react significantly to changes in output. This has been one of the arguments most commonly advanced in favour of reforming the labour institutions. Nevertheless, the reforms of the labour institutions introduced from 1991 onwards showed that this argument was unfounded: the erosion of those institutions and the weak response of employment to the cycle of expansion in 1991-4 provides a reliable indication that this view is not entirely adequate to explain the phenomenon.

Even so, there are other views that seem to offer more convincing explanations of the weak response of employment to the economic cycle. Montoya (1998) maintains that one of the economic policies typical of the Argentinian economy was the stop-go cycle, with a monetary policy that had a lasting impact on wage levels and the labour market. This is an indication, he says, that in actual fact the problem has more to do with the cycle than with employment. Altimir and Beccaria (1999) maintain that the period was characterized by two contrasting effects that took place within the economy. One was positive: the result of economic expansion that favoured the creation of jobs and was associated with the rise in consumption generated by price stabilization and increased investment. But this effect was counteracted by the application of economic reforms and the restructuring of production, which tended to eliminate jobs and to reduce the output elasticity of employment, both by substituting capital and imported inputs for labour and by raising total factor productivity.

43 In formal terms, the output elasticity of employment is defined as the quotient between the marginal function of employment and its average function, and can be expressed as: $[(\partial T / \partial P I B) /(T / P I B)]$. 
Llach and Llach (1998) argues that in a process of economic restructuring such as that experienced in Argentina there is a period of adjustment during which increased employment in the expanding sectors fails to compensate for falls in employment in the declining sectors. This asymmetry may be due to institutional rigidity, varying intensity of use of factors between different activities (resulting from a change in relative prices that reduces the price of capital goods) or the existence of a mismatch between skills supply and demand. Adopting this line of analysis, labour problems are really attributable not to a lack of dynamism in the goods market or a surplus supply of labour but to a mismatch between the type of workforce for which demand exists and the type of workforce available; this is basically affected by educational differentials indicative of the existence of markets with excess supply and those with excess demand. 44 This has been another of the principal arguments advanced in favour of creating a flexible regulatory framework, because what is needed, by this view of things, is an adjustment between available jobs and the labour supply; and a high degree of internal mobility of labour within companies, industries and regions would be one way of promoting this theoretical mismatch.

Having examined the various arguments that provide attempted approaches to the interpretation of the problem, we can identify as a common feature of this process the existence of a demand that is incapable of absorbing and generating employment once a process of reform and opening-up has taken place. On the other hand, as we shall see shortly, the growth of output was reflected more by increases in activity than by increases in employment. What seems to take place during the economic cycle is that during the phases of recession (the 1980s) falling employment is not reflected by an immediate reduction in jobs, owing to the labour regulations applicable to the labour market. In other words, the costs associated with dismissals meant that the fall in output is not fully reflected by a reduction in the quantity of employment. Conversely, changes in employment during the periods of economic recovery appear to be slow, and the positive effects on employment become apparent only in the long term. Moreover, if there has been an accumulation of labour at the times of crisis, this would also influence the immediate increase in employment in response to positive shocks. In Latin America, the Chilean experience of the 1980s is another case where increased output was matched by increases in unemployment. Tokman (1998) contends that the result of the policies of adjustment and stabilization applied in Chile in 1974-5 was a substantial increase in output and productivity, but accompanied by rises in unemployment and informal working. And it was not until six years had passed that employment increased sufficiently to reduce the levels of unemployment.

In summary, the characteristics specific to the phase of output conversion, which come into being during the period of growth and subsequently remain in place, explain the negative results on the labour side and the weak response of employment to the cycles of expanding economic activity.

\footnotetext{
44 The author demonstrates that in some countries where processes of structural reform have taken place it would appear that low output elasticity of demand is the rule rather than the exception during the phase of adjustment. Once the reform process is at an end, elasticity becomes high once again, as happened in the case of Argentina.
} 


\subsubsection{Changes in the productivity of labour}

In this section we will be examining the changes in labour productivity, one of the factors that has had the greatest impact on the recovery of employment, and especially of industrial employment. $45 \mathrm{We}$ may define this as the change in industrial production per unit of labour at a given time.

\section{Chart 9}

\section{Changes in industrial output and industrial employment}

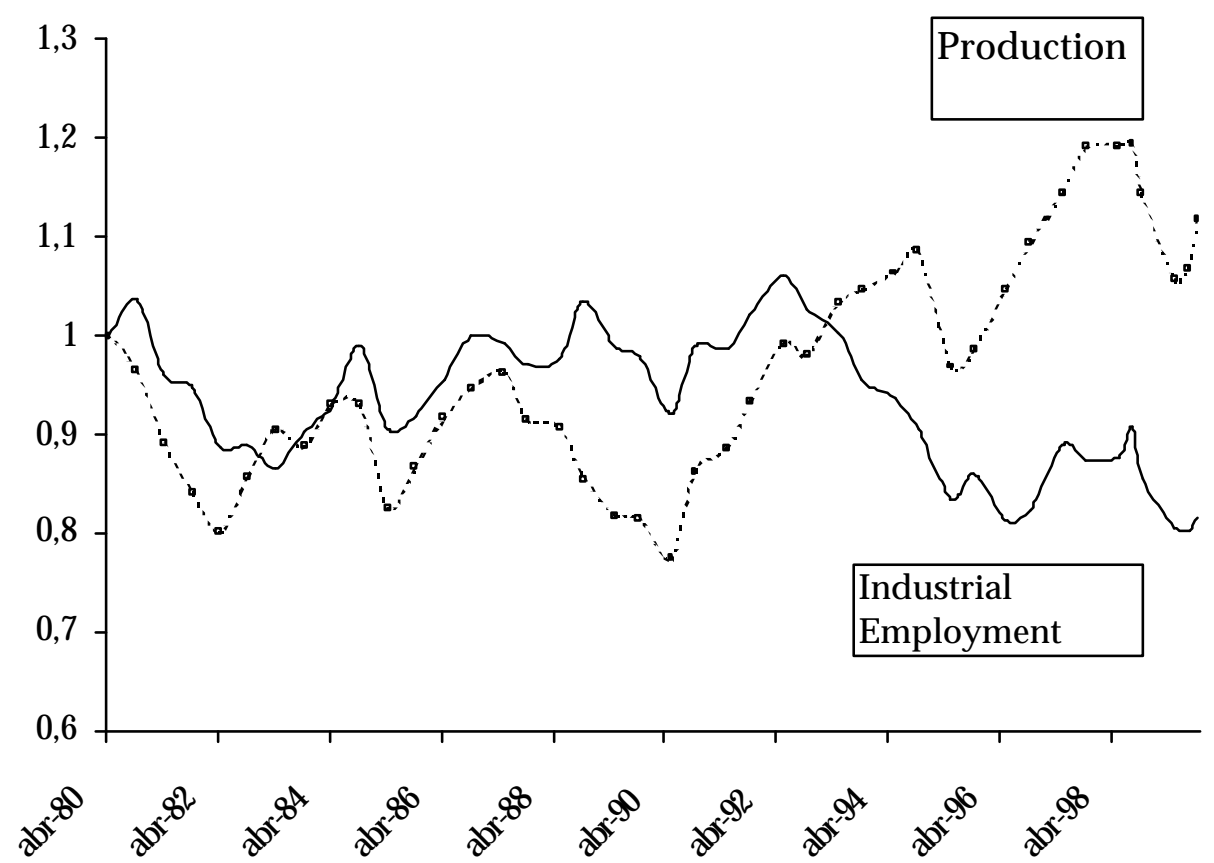

Source: author's calculations based on INDEC and Ministry for Economic Affairs.

In the 1980s, both employment and production in industry followed uniform trends in terms of the cycles of contraction and expansion. During this period, industrial employment and production fell by $8 \%$ and $18 \%$ respectively. But from 1990 onwards the patterns of industrial employment and production diverge: while industrial output rose by $35 \%$, the decrease in manufacturing employment was $13 \%$. The widening gap between manufacturing employment and industrial output shows the increasing inability of the industrial sector to create jobs, or even to maintain existing ones.

Reforms tending towards openness, privatizations and the greater significance of the services sector came simultaneously with a sharp increase in productivity, especially during the 1990s. Chart 10 shows the productivity index per person employed in industry 46 and the changes in the real industrial wage. The series summarizes what has taken place during the past two decades. In the 1980s it fell by $12 \%$, while the recovery during the 1990 s was overwhelming - between May 1990 and May 1999 the increase was 65\%. This rise offers one of the best explanations of the performance of the labour market. The fall in industrial employment went hand in hand with an increase in production levels, but it was the fall in

45 This analysis focuses on industrial employment, because two thirds of job losses take place in manufacturing industry and have a particular impact on men and on heads of households.

46 The productivity index is the quotient between industrial production and those employed in industry. 
employment that had the greater impact on the increases in productivity and, to a lesser extent, the rise in production.

To some extent, the powerful growth of labour productivity during the 1990s can also be associated with the poor economic performance of the previous decade. In a context where productivity levels lagged further and further behind, the margin for the kind of increase that took place was very wide. ${ }^{47}$ An aspect of this trend that must be taken into account, however, is that if variations in productivity are greater than variations in output, the result is increased unemployment, and that is what occurred during the 1990s, and especially in the first five years of the decade. The pattern of industrial employment, as stated by Frenkel and González (1999), reflected the impact of three factors: the growth of industrial production (positive), the effect of direct substitution of local industrial production by imports in the additional demand (negative) and a process of reduction of labour per unit of production as a result (negative).

Another of the features apparent in this process is the widening gap between labour productivity and wage development. The profits resulting from increased productivity from 1991 onwards were not reflected by improvements in real wages; indeed, apart from the widening of the gap, average wages in real terms followed a downward trend, which still further increased the divergences from labour productivity. This, at least in theoretical terms, is an important cause of deteriorating distribution, owing to the fact that the gains in productivity benefited the financial sector, or sectors of the economy where labour is not a relevant factor.

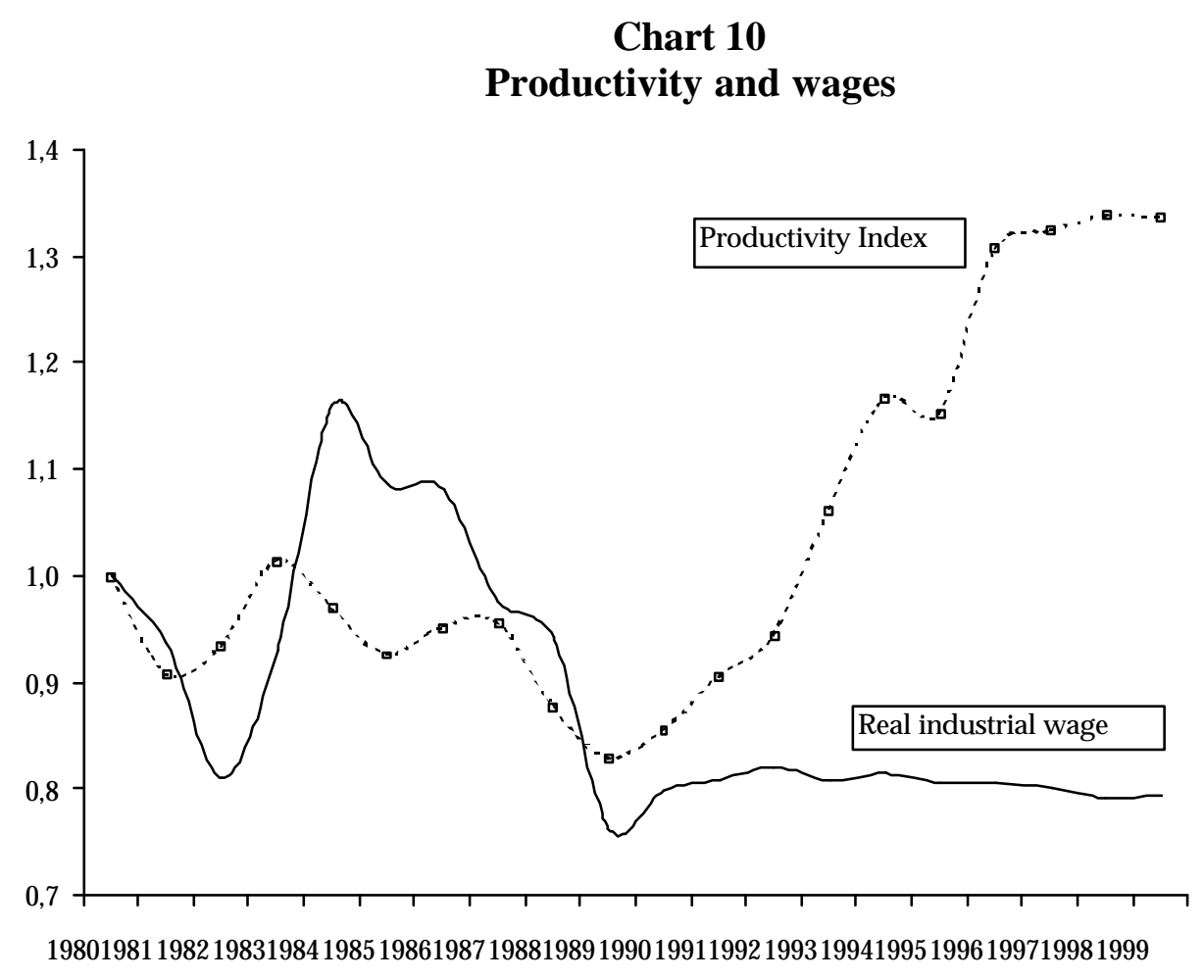

Source: author's calculations based on INDEC and ECLAC.

47 The reason for this is that during the 1980 s the jobs created were notable for their low productivity,
especially those associated with the public sector and the self-employed. 
In summary, the increase in the output of labour is the characteristic feature of the increase in the productivity of labour. What occurs in this process is a fall in employment while the "winners" from the reconversion - those who managed to retain their jobs - derived no increase in earnings on the basis of the productivity improvements that had taken place in the preceding years.

\section{DETERMINANTS OF INEQUALITY}

\subsection{Econometric analysis}

With a view to examining how the developments described above affected wage distribution, we used the OLS method to estimate various equations to explain the calculated measurements of inequality. The series correspond to the EPH for the period 1980-99. Owing to the fact that various factors affect the trend of inequality, we decided to separate the determinants into three categories, which would enable us to analyse their effects separately. The variables used here thus basically correspond to what we believe to be the most relevant determinants for the purposes of explaining inequality and are grouped in three categories: labour, macroeconomic and institutional factors, summarized in table 11.

The first model relates to the macroeconomic hypothesis. We attempt to analyse the extent to which changes in the macroeconomic aggregates influenced wage inequality.

$$
\begin{aligned}
& I_{1}=C+\beta_{1} A C T+\beta_{2} I N V+\beta_{3} I M P+\beta_{4} D E S+\beta_{5} D U M M Y_{1}+\beta_{6} D U M M Y_{2}+ \\
& \beta_{7} D U M M Y_{3}+\varepsilon
\end{aligned}
$$

where $I_{1}$ is the coefficient $Q_{5} / Q_{1}, C$ is a constant, $A C T$ is the gross domestic product, $I N V$ is gross domestic fixed investment, IMP is imports and DES is the rate of unemployment, while the three $D U M M Y$ variables correspond to the rate of inflation over the period studied. The intuitive expectation would be that an increase in the CPI demonstrates a positive correlation with levels of inequality. However, when the prices variable is regressed, without any modifications, the sign of the variable is negative. That variable had a dominant effect throughout the period studied, reaching levels in the region of $4,000 \%$, or levels in the vicinity of zero throughout the 1990s. This provides us with an indication that there was a change in the trend and that, if this is not taken into account, the dominant effect is negative. When the variable is controlled by the interaction effect, we can distinguish the positive and negative effects on the levels of inequality. Specifically, the consumer price index has been multiplied by three dummy variables representing the periods 1980-90, 1991-2 and 1992-9.

The underlying hypotheses are that a rise in $A C T I V$, an increase in $I N V$ or a rise in $D E S$ leads to a reduction of inequality, while an increase in the CPI (DUMMY) shows a positive or negative correlation with the levels of inequality, depending on the period analysed. Whichever of the three models we analyse, a positive coefficient is regressive, since it would suggest a deterioration, while in the converse case it would be progressive in a similar sense. 
The second model studied represents the labour hypothesis and is defined as:

$$
I_{2}=C+\lambda_{1} S A L_{1}+\lambda_{2} S A L_{2}+\lambda_{3} F E M+\lambda_{4} I N F+\lambda_{5} I N S+\lambda_{6} P R O+\varepsilon
$$

where $I_{2}$ is the $\operatorname{Atk}(0.5)$ coefficient, $C$ is a constant, $S A L_{1}$ is the average wage of unskilled workers, $S A L_{2}$ is the average wage of skilled workers, FEM is the female activity rate, INF is the percentage of informal employees, ${ }^{48}$ INS is an economic insecurity index ${ }^{49}$ and $P R O$ is the productivity of labour. The first two variables are wages related to educational levels. Their purpose is nothing more than to illustrate the relationship between wage differentials and inequality, bearing in mind that the inequality of an aggregate (employees) may break down into inequality between subsets (wages between different educational sets) and inequality within those subsets. The reason for their inclusion is the hypothesis that returns to education may have increased because demand has become more skill-biased. The sign of $S A L_{1}$ should be negative while that of $S A L_{2}$ should be positive. It has been argued that the increase in FEM may affect labour supply and have an impact on wage inequality. A positive correlation is expected between wage inequality and $I N F$ and with respect to an increase in the variable INS. Finally, we expect a negative correlation between $P R O$ and wage inequality.

The third and last model is used to analyse the institutional factors:

$I_{3}=C+\gamma_{1} M I N_{1}+\gamma_{2} M I N_{2}+\gamma_{3} B E N E F+\gamma_{4} I N S T+\varepsilon$

where $I_{3}$ is the Atk coefficient (2.5), $C$ is a constant, $M I N_{1}$ is the minimum wage at constant values, $M I N_{2}$ is the percentage of employees with wages below the minimum, BENEF is the percentage of employees receiving no social benefit, while INST is an approximation to the institutional effect on wages. One of the hypotheses put forward in this study is that wages have been affected by factors that we might call institutional. If we regress the wage on dummy variables that represent each of these stages defined in table 3, we have:

\footnotetext{
48 We define the informal sector as an "unofficial" sector. For the construction of the indicator, we adopt the methodology proposed by Monza and Lopez (1995). This excludes domestic activities, the underemployed and sectors regarded a priori as formal. Of the remaining group, the definition "informal" is applied to those working in establishments employing fewer than six people, whatever the level of qualification, but with incomes lying in the first four deciles of the distribution corresponding to their skills group.

49 We have applied the indicator defined by Beache and Slotsve (1996). We divide the proportion of employees in low-income sectors (below 0.5 times the median) by the proportion of employees in middle- to low-income sectors (below 1.5 times the median). Thus we measure the probability that an individual whose income is located in the middle group or below may be "polarized" towards the lowincome group.
} 
$w_{t}=\beta_{0}^{*}+\beta_{1}^{*} D_{t}^{1}+\beta_{2}^{*} D_{t}^{2}+\beta_{3}^{*} D_{t}^{3}+\beta_{4}^{*} D_{t}^{4}+\mu_{t}$

where:

$\beta_{0}^{*}=$ mean $w_{t}$ in period $D_{t}^{5}$

$\beta_{1}^{*}=\beta_{1}-\beta_{5}$

$\beta_{2}^{*}=\beta_{2}-\beta_{5}$

$\beta_{3}^{*}=\beta_{3}-\beta_{5}$

$\beta_{4}^{*}=\beta_{4}-\beta_{5}$

$\mu_{t}=$ wage free of the institutional effect.

The errors of the model represent the wage corrected for the institutional effect, whereby $I N S T=w_{t}-\mu_{t}$ is an approximate measurement of the institutional effect on wages.

With regard to the signs of the variables used in this model, an increase in $M I N_{1}$ is expected to reduce inequality while $M I N_{2}$ has a positive correlation with wage inequality. 50 With regard to $B E N E F$, we expect an increase here to generate an increase in the coefficients of wage inequality. Finally, the sign of INST will depend on how restrictive institutional behaviour was during the period studied. In the present work, it is argued that the restrictions that affect wages and the erosion of the labour institutions had a negative impact on wage inequality, so that the expected sign is positive.

\footnotetext{
50 Although the minimum wage sets an explicit floor on the wage distribution, acting as a backstop for those at the bottom end of the wage distribution and reducing dispersion, Fortin and Lemieux (1997) contend that cases exist where a high minimum wage increases wage dispersion. This, they say, occurs if wage distribution is sharply inclined to the right and the minimum wage simply acts as a wedge on wage distribution. Another alternative would be if the target group comprised low-waged workers, in which case a minimum wage would reduce the level of wage inequality in the labour market, shifting the affected workers towards a higher part of the distribution. But since only a fraction of low-paid workers would benefit from these programmes, their impact on wage inequality could be ambiguous.
} 
Table 11

Summary of variables used in the econometric models

Dependent Variables

\begin{tabular}{|l|l|l|l|}
\hline $\begin{array}{c}\text { Inequality } \\
\text { indices }\end{array}$ & \multicolumn{1}{|c|}{ Definition } & $\begin{array}{c}\text { Expected } \\
\text { sign }\end{array}$ & \multicolumn{1}{|c|}{ Source } \\
\hline$I I$ & Q5/Q1 & & EPH \\
\hline$I 2$ & Atkinson index (0.5) & & EPH \\
\hline$I 3$ & Atkinson index (2.5) & & EPH \\
\hline
\end{tabular}

Independent variables

\begin{tabular}{|l|l|c|l|}
\hline $\begin{array}{c}\text { Macroecon. } \\
\text { conditions }\end{array}$ & \multicolumn{1}{|c|}{ Definition } & $\begin{array}{c}\text { Expected } \\
\text { sign }\end{array}$ & \multicolumn{1}{|c|}{ Source } \\
\hline$A C T$ & Gross domestic product & $<0$ & ECLAC, BCRA \\
\hline$I N V$ & Gross domestic fixed investment & $<0$ & $\begin{array}{l}\text { ECLAC, various } \\
\text { sources }\end{array}$ \\
\hline$D E S$ & Unemployment rate & $>0$ & INDEC \\
\hline$D U M M Y_{1}$ & $\begin{array}{l}\text { Consumer price index x Dummy: 1 for the } \\
\text { period 1980-90 and 0 for the remainder }\end{array}$ & $>0$ & INDEC \\
\hline$D U M M Y_{2}$ & $\begin{array}{l}\text { Consumer price index x Dummy: 1 for the } \\
\text { period 1991-2 and 0 for the remainder }\end{array}$ & $<0$ & INDEC \\
\hline$D U M M Y_{3}$ & $\begin{array}{l}\text { Consumer price index x Dummy: 1 for the } \\
\text { period 1992-9 and 0 for the remainder }\end{array}$ & $<0$ & INDEC \\
\hline
\end{tabular}

\begin{tabular}{|l|l|c|l|}
\hline $\begin{array}{l}\text { Labour } \\
\text { market }\end{array}$ & \multicolumn{1}{|c|}{ Definition } & $\begin{array}{c}\text { Expected } \\
\text { sign }\end{array}$ & \multicolumn{1}{|c|}{ Source } \\
\hline$S A L_{1}$ & $\begin{array}{l}\text { Real wage of unskilled workers (<7 years' } \\
\text { education) }\end{array}$ & $<0$ & EPH \\
\hline$S A L_{2}$ & $\begin{array}{l}\text { Real wage of skilled workers (17 years' } \\
\text { education) }\end{array}$ & $>0$ & EPH \\
\hline$I N F$ & Percentage of employees in the informal sector & $>0$ & EPH \\
\hline$F E M$ & Female activity rate & $>0$ & EPH \\
\hline$I N S$ & $\begin{array}{l}\text { Ratio of \% employees below 0.5 x median/\% of } \\
\text { employees below 1.5 x median }\end{array}$ & $<0$ & EPH \\
\hline$P R O$ & Labour productivity & $\begin{array}{l}\text { EPH, Various } \\
\text { sources }\end{array}$ \\
\hline
\end{tabular}

\begin{tabular}{|l|l|c|l|}
\hline Institutional & \multicolumn{1}{|c|}{ Definition } & $\begin{array}{c}\text { Expected } \\
\text { sign }\end{array}$ & \multicolumn{1}{|c|}{ Source } \\
\hline$M I N_{1}$ & Real minimum wage & $<0$ & $\begin{array}{l}\text { FIEL, various } \\
\text { sources }\end{array}$ \\
\hline$M I N_{2}$ & $\begin{array}{l}\text { Percentage of employees below the minimum } \\
\text { wage }\end{array}$ & $>0$ & $\begin{array}{l}\text { EPH, various } \\
\text { sources }\end{array}$ \\
\hline$B E N E F$ & Percentage of employees without social benefits & $>0$ & EPH \\
\hline$I N S T$ & Institutional effect on wages & $>0$ & Various sources \\
\hline
\end{tabular}


In general, we find a degree of regularity in the results, irrespective of the coefficients of inequality used, although the strongest estimates were found for the Atkinson coefficients and the ratio between extreme quintiles. Similarly, the coefficients of regression are statistically significant, and an interesting fact that emerges from the various models relates to the high levels of the coefficient of determination (between 55\% and 80\%), taking account of the quantity of determinants that may influence wage distribution. ${ }^{51}$ One fact to be borne in mind regarding the majority of the coefficients used has to do with the ranges and magnitudes used for each variable, which are indices in some cases and monetary values or rates in others, so that in the majority of cases the values of the coefficients are very low, although this does not give rise to any statistical problem.

Table 12

\section{Macroeconomic model results}

Model Summary

\begin{tabular}{|c|c|c|c|c|c|c|c|c|c|c|}
\hline \multirow[b]{2}{*}{$\mathrm{R}$} & \multirow[b]{2}{*}{ R Square } & \multirow[b]{2}{*}{$\begin{array}{l}\text { A djusted } \\
\text { R Square }\end{array}$} & \multirow{2}{*}{$\begin{array}{c}\text { Std. Error } \\
\text { of the } \\
\text { Estimate }\end{array}$} & \multicolumn{5}{|c|}{ Change Statistics } & \multirow[b]{2}{*}{ Durbin- Watson } & \multirow[b]{2}{*}{ Akaike } \\
\hline & & & & $\begin{array}{c}\text { R Square } \\
\text { Change }\end{array}$ & F Change & df1 & df2 & $\begin{array}{c}\text { Sig. F } \\
\text { Change }\end{array}$ & & \\
\hline 0,888 & 0,789 & 0,734 & 0,0867 & 0,789 & 14,382 & 7 & 27 & 0,000 & 1,65 & $-4,39$ \\
\hline
\end{tabular}

Predictors: (Constant), DUMMY $2, \mathrm{DUMMY}_{1}, \mathrm{DUMMY}_{3}$, INV , DES, ACT, IMP

Dependent Variable: 12

Coefficients

\begin{tabular}{|c|c|c|c|c|c|c|c|}
\hline & \multicolumn{2}{|c|}{ Unstandardized Coefficients } & $\begin{array}{c}\text { Standardized } \\
\text { Coefficients }\end{array}$ & \multirow[t]{2}{*}{$\mathrm{t}$} & \multirow[t]{2}{*}{ Sig. } & \multicolumn{2}{|c|}{$95 \%$ Confidence Interval for B } \\
\hline & $\mathrm{B}$ & Std. Error & Beta & & & Lower Bound & Upper Bound \\
\hline$\overline{\text { (Constant) }}$ & 2,115503684 & 0,347340736 & & 6,091 & 0,000 & 1,402819358 & $\overline{2,82818801}$ \\
\hline $\mathrm{ACT}$ & $-0,000339747$ & 0,000164472 & $-0,7258$ & $-2,066$ & 0,049 & $-0,000677217$ & $-2,27808 E-06$ \\
\hline INV & $-0,000373378$ & 0,000185715 & $-1,5912$ & $-2,010$ & 0,054 & $-0,000754432$ & 7,67894E-06 \\
\hline IMP & 0,000581365 & 0,000160221 & 3,4801 & 3,629 & 0,001 & 0,000252618 & 0,000910112 \\
\hline DES & 0,009704682 & 0,003656315 & 0,6530 & 2,654 & 0,013 & 0,002202543 & 0,017206821 \\
\hline DUMMY $_{1}$ & 8,16005E-08 & 3,06715E-08 & 0,2579 & 2,660 & 0,013 & 1,86679E-08 & 1,44533E-07 \\
\hline $\mathrm{DUMMY}_{2}$ & $-3,32517 E-09$ & 9,15904E-10 & $-0,7167$ & $-3,630$ & 0,001 & $-5,20445 E-09$ & $-1,44589 E-09$ \\
\hline $\mathrm{DUMMY}_{3}$ & $-3,5988 \mathrm{E}-09$ & 7,19282E-10 & $-1,7723$ & $-5,003$ & 0,000 & $-5,07464 E-09$ & $-2,12295 E-09$ \\
\hline
\end{tabular}

Dependent Variable: II

Table 12 gives the results for the model with the ratio between quintiles as the dependent variable and macroeconomic variables as independent. The results show that the macroeconomic aggregates such as ACTIV and INV reduce the levels of economic inequality. This might suggest that during recessions, which are fairly common in the Argentinian economy, the increases in inequality occur because the wages of the workers in the low part of the distribution fall further than those in the upper part, hence the negative effect on inequality. The converse occurs with the variable DES, which acts regressively on the coefficients of inequality. This result agrees with the majority of studies which empirically analyse the relationship between macroeconomic conditions and inequality and reveal a close connection through the labour market. Thus, Blinder and Esaki (1978), MacPhail (1998),

\footnotetext{
51 As argued by Kanbur and Lusting (1999), wage distribution is the result of a complex number of forces which, at times, act in the same direction, though it is also possible that they may counteract one another and that their effects may be reciprocally cancelled out. In this sense, the statistically significant results tell us that some of these forces are being estimated in the present models.
} 
Jäntti (1994), González and Menéndez (1999) and Blejer and Guerrero (1990) find that the changes in economic conditions affected wage inequality through the rate of unemployment, this regular pattern occurring irrespective of methodology and of the region or state to which the study is applied. For example, in the case of countries belonging to the OECD, Galbraith (1997) shows that the correlation in time and between states between inequality and employment is consistently positive. The imports variable (IMP) with a positive sign corroborates the effect this might have on labour demand and on wage inequality.

Another of the channels through which the changes in the macroeconomic conditions affect levels of inequality has been the variations in price levels. It was noted previously that there is an important change in the tendency of this variable, and that if it is not controlled the dominant effect is the negative one. This fact is very striking, although it has a concrete explanation. Macroeconomic price stabilization measures will often achieve their political purpose, but truncating this relationship and generally with high associated costs, which explains the dominance of the negative effect represented by the events of the 1990s, with falling prices and increasing inequality. The positive and significant sign of the consumer price index in the 1980s (DUMMY1) indicates that price increases had a regressive effect on the levels of wage inequality. This result is almost invariable in studies that link macroeconomic conditions and distributive aspects, among them Nolan (1989) and Blejer and Guerrero (1990). In the "developing" countries, inflation acts as a regressive tax in the sense that the low-income segments cannot protect their real incomes because their wages are not index-linked and they rarely own other assets where real values can be maintained during times of inflation (Blejer and Guerrero, 1990). This does not happen in the case of the highincome sectors, which can sustain and even benefit from the price rises, a fact that causes a further increase in wage dispersion. The reduction of prices resulting from rapid stabilization associated with "peso-dollar" convertibility and policies of reform and structural adjustment that resulted in near-zero inflation had a negative impact on levels of wage inequality. Monitoring the change in the price trend, we can see that in the 1990s, in other words in the period of stabilization $\left(D U M M Y_{2}\right)$ and in the period of longer-term adjustment $\left(D U M M Y_{3}\right)$, falls in prices generate increases in wage inequality. 52

Table 13 shows the model that includes labour variables. The first two relate to wages by educational levels. While the real wage for those who have completed university studies shows a positive correlation with the inequality index, this is not the case with wages of lowqualified persons. This is the same thing as saying that the wider the wage gap between skilled and unskilled workers, the greater the wage inequality between the recipients of wages. 53 In other words, unequal access to education is an additional source of inequality, in that it legitimizes or increases existing differences. ${ }^{54}$ As stated by Cornia (1999), unequal

\footnotetext{
52 The measures that accompany stabilization policies (reduction of the deficit, changes in interest rates, spending cuts, increases in tax rates, privatizations, etc.) produce rapid macroeconomic effects. However, as noted by Cornia (1999), the IMF itself acknowledges that these policies could give rise to sustained recessions and adverse results in distributive terms.

53 This conclusion is similar to that reached by Larrañaga (1999) in the case of Chile.

54 Moreover, in a context of limited resources and in view of the difficulty of catering for the more disregarded sectors, the pressure to favour those with greater ability is substantial (Filmus, 1996). This is what occurs with education in Argentina, and the causal relationship should be specified exactly: membership of a low-income sector means that it will be impossible to achieve an acceptable educational level.
} 
access to education has traditionally been a source of inequality in developed countries, but especially so in developing countries, and this correlation between inequality and education has been well established. ${ }^{5}$ For example, Székely and Londoño (1998) state that the excessive inequality apparent in Latin America today, by comparison with the average for other countries of the world, is clearly associated with the level, composition and distribution of its assets, the most important of which is human resources. The inadequacy of their level explains almost one third of the excess of inequality. Moreover, in the case of Argentina, the shift in demand towards skilled workers resulted in a rapid increase in their wages, whereas that increase was minimal for low-skilled workers, thus giving rise to another source of wage dispersion.

Table 13

\section{Labour model results}

Model Summary

\begin{tabular}{|c|c|c|c|c|c|c|c|c|c|c|}
\hline \multirow[b]{2}{*}{$\mathrm{R}$} & \multirow[b]{2}{*}{ R Square } & \multirow[b]{2}{*}{$\begin{array}{l}\text { Adjusted } \\
\text { R Square }\end{array}$} & \multirow{2}{*}{$\begin{array}{c}\text { Std. Error } \\
\text { of the } \\
\text { Estimate }\end{array}$} & \multicolumn{5}{|c|}{ Change Statistics } & \multirow[b]{2}{*}{ Durbin- Watson } & \multirow[b]{2}{*}{ A kaike } \\
\hline & & & & $\begin{array}{c}\text { R Square } \\
\text { Change }\end{array}$ & F Change & df1 & df2 & $\begin{array}{c}\text { Sig. } \mathrm{F} \\
\text { Change }\end{array}$ & & \\
\hline 0,906 & 0,820 & 0,782 & 0,0064 & 0,820 & 21,268 & 6 & 28 & 0,000 & 2,14 & $-9,674$ \\
\hline
\end{tabular}

Predictors: (Constant), PRO, SAL 2 , INS, INF, FEM, SAL 1

Dependent Variable: 12

Coefficients

\begin{tabular}{|c|c|c|c|c|c|c|c|}
\hline & \multicolumn{2}{|c|}{ Unstandardized Coefficients } & $\begin{array}{c}\text { Standardized } \\
\text { Coefficients }\end{array}$ & \multirow[t]{2}{*}{$\mathrm{t}$} & \multirow[t]{2}{*}{ Sig. } & \multicolumn{2}{|c|}{$95 \%$ Confidence Interval for B } \\
\hline & $\mathrm{B}$ & Std. Error & Beta & & & Lower Bound & Upper Bound \\
\hline (Constant) & 0,147412896 & 0,037964396 & & 3,883 & 0,001 & 0,069646355 & 0,225179437 \\
\hline $\mathrm{SAL}_{1}$ & $-0,000143739$ & 3,58175E-05 & $-0,7870$ & $-4,013$ & 0,000 & $-0,000217108$ & $-7,037 E-05$ \\
\hline $\mathrm{SAL}_{2}$ & 7,2187E-05 & $2,81269 \mathrm{E}-05$ & 0,4859 & 2,566 & 0,016 & 1,45717E-05 & 0,000129802 \\
\hline FEM & 0,002137837 & 0,000640839 & 0,6164 & 3,336 & 0,002 & 0,000825138 & 0,003450535 \\
\hline INF & 0,284636709 & 0,104945888 & 0,3536 & 2,712 & 0,011 & 0,069664802 & 0,499608617 \\
\hline INS & 0,001546354 & 0,000463085 & 0,3552 & 3,339 & 0,002 & 0,000597767 & 0,002494941 \\
\hline PRO & $-0,037057346$ & 0,011504141 & $-0,5533$ & $-3,221$ & 0,003 & $-0,060622511$ & $-0,013492181$ \\
\hline
\end{tabular}

Dependent Variable: 12

With regard to the FEM variable, we confirm that there is a positive and significant sign, indicating that the increased female participation in employment has generated an increase in total inequality. This does not corroborate the hypothesis of substitution between men and women, although what it does show is that the rise in women's participation, with higher educational standards and lower wages than men, and greater inequality among women themselves, has a regressive impact on total inequality. The coefficient of the variable INF is positive and significant. The characteristics of this group are low skill levels, employment in retail trade sectors or the provision of repair and personal services, longer than average working hours and absence of pension provision; in general, they are actively seeking alternative employment. Although informal employment is a characteristic associated with the self-employed, the phenomenon has also become more widespread among employees, and in

55 Many studies find a strong correlation between investment in human resources by individuals of one generation and the earned income available to them in the future. An interesting review will be found in Psacharopoulos (1985). 
terms of composition it is a significant variable for the purposes of understanding wage inequality. The sign of the INS variable, as expected, is positive. Precarious employment in general is typified by clandestine working, an increase in self-employment or membership of low-waged sectors. But, in addition to these factors, there is another that has been becoming increasingly significant since the early 1980s: wage instability. There are sectors where wages are not only low but subject to many fluctuations, and where the possibility of slipping into the zone of unemployment or greater informality is very high. The sign of the variable PRO is negative, indicating that increases in productivity lead to decreases in levels of inequality. This result, while theoretically correct in the sense that increases in productivity generate greater prosperity and higher living standards among the population, leaves some room for doubt in view of the performance of this variable during the 1990s, when significant increases in the context of openness and deregulation of the economy were reflected not by higher wages but by falls in employment. The variable has been corrected for its trend but the sign remains dominant.

Table 14 shows the results for the model with institutional variables. We can verify that the increase in the minimum wage generates a reduction in levels of inequality. This result is in line with the findings of the majority of empirical studies analysing the correlation between minimum wage and inequality. The dominant effect is probably redistribution towards lowwaged workers and the containment effect, which does not allow workers in the lower part of the distribution to fall below a threshold defined as a minimum in wage terms. When this occurs, and there are workers situated below this threshold, what is produced is an increase in wage inequality. This is what we measure with the variable $M I N_{2}$, which records the percentage of employees below the minimum. This merely corroborates the importance of distributive mechanisms in limiting the increase in inequality and increasing the welfare of workers on low wages. The positive sign of the variable BENEF shows that higher levels of deficient social protection increase wage inequality. This variable accounts for employees who, in their main occupation, receive no compensation for dismissal, holiday pay, Christmas bonus, pension entitlement, job security or social services - in other words, jobs that provide no social benefits. The basis of these contracts lies in the reforms implemented in the labour market and their influence on inequality is rooted in the fact that segmentation has taken place between formal, protected employment on the one hand and precarious, unprotected employment on the other, the latter also earning much lower wages. ${ }^{56}$ Finally, the sign of the variable INST as it affects wage inequality is positive and significant. This means that the institutional factors that affected wages were regressive in terms of wage inequality. This result is explained by that stages of wage determination analysed in this study, characterized by the administration and freezing of wages, restrictions on collective bargaining, etc.

56 In 1980, the proportion of employees receiving all benefits was $68 \%$, while those who received no benefits at all accounted for $12 \%$. In 1999, those receiving all benefits numbered $57 \%$, while the percentage of those receiving no benefits at all had trebled to $35 \%$ of employees. 
Table 14

Institutional model results

\begin{tabular}{|c|c|c|c|c|c|c|c|c|c|c|}
\hline \multirow[b]{2}{*}{$\mathrm{R}$} & \multirow[b]{2}{*}{ R Square } & \multirow[b]{2}{*}{$\begin{array}{l}\text { Adjusted } \\
\text { R Square }\end{array}$} & \multirow{2}{*}{$\begin{array}{l}\text { Std. Error } \\
\text { of the } \\
\text { Estimate }\end{array}$} & \multicolumn{5}{|c|}{ Change Statistics } & \multirow[b]{2}{*}{ Durbin- Watson } & \multirow[b]{2}{*}{ A kaike } \\
\hline & & & & $\begin{array}{c}\text { R Square } \\
\text { Change }\end{array}$ & F Change & df1 & df2 & $\begin{array}{c}\text { Sig. F } \\
\text { Change }\end{array}$ & & \\
\hline 0,770 & 0,593 & 0,539 & 0,0363 & 0,593 & 10,924 & 4 & 30 & 0,000 & 1,71 & $-6,348$ \\
\hline
\end{tabular}

Predictors: (Constant), INST, MIN 2 , BENEF, MIN 1

Dependent Variable: I3

Coefficients

\begin{tabular}{|c|c|c|c|c|c|c|c|}
\hline & \multicolumn{2}{|c|}{ Unstandardized Coefficients } & \multirow{2}{*}{$\begin{array}{c}\begin{array}{c}\text { Standardized } \\
\text { Coefficients }\end{array} \\
\text { Beta } \\
\end{array}$} & \multirow[t]{2}{*}{$t$} & \multirow[t]{2}{*}{ Sig. } & \multicolumn{2}{|c|}{ 95\% Confidence Interval for B } \\
\hline & $\mathrm{B}$ & Std. Error & & & & Lower Bound & Upper Bound \\
\hline (Constant) & 0,3472944 & 0,039269137 & & 8,844 & 0,000 & 0,267096122 & 0,427492678 \\
\hline $\mathrm{MIN}_{1}$ & $-0,000313523$ & 0,000109155 & $-0,4820$ & $-2,872$ & 0,007 & $-0,000536447$ & $-9,05986 E-05$ \\
\hline $\mathrm{MIN}_{2}$ & 0,383374927 & 0,094118962 & 0,6271 & 4,073 & 0,000 & 0,191158362 & 0,575591492 \\
\hline BENEF & 0,004460779 & 0,001049087 & 0,5925 & 4,252 & 0,000 & 0,002318257 & 0,006603302 \\
\hline INST & 0,000112304 & 3,84177E-05 & 0,3598 & 2,923 & 0,007 & 3,38446E-05 & 0,000190763 \\
\hline
\end{tabular}

Dependent Variable: 13

\subsection{Decomposition of the Theil index}

An alternative method of analysing the inequality determinants is on the basis of the decomposition of the Theil index. One of the useful characteristics of this coefficient is that it can be broken down for different subsets of the population, thus giving the contribution made by each population subset to total inequality. Following Shorrocks (1980), we can break down the measure of inequality shown in (4) as follows:

(5) $\quad T=\sum_{j} \frac{y_{j}}{y} T_{j}+\sum_{j} \frac{y_{j}}{y} \ln \frac{y_{j} / y}{N_{j} / N}$

where:

$y_{j}, j=1 \ldots N$ represents the total income of set $j$;

$y$ is total income;

$T_{j}$ is the Theil for each population subset as defined in (4) and

$N_{j}, j=1 \ldots N$ is the population in each selected set, with $\sum_{j=1}^{J} N_{j}=N$

The first part of the sum represents the contribution to total inequality made by dispersion within the groups (intragroups component), while the second represents the contribution made by dispersion between the groups (intergroups component). The intergroup component may be regarded as the portion of inequality explained by the variable $j$, which is the variable defining the groupings analysed and in general is defined as the gross 
contribution to inequality, while the intragroup component is the portion not explained by that variable. 57

The breakdown of total inequality is given for the years 1980, 1985, 1990, 1995 and 1999 by the categories summarized in table 15 .

Table 15

\section{Decomposition of the Theil coefficient: definition of variables}

A. Sex
1. Male
2. Female

B. Educational level

1. No education

2. Incomplete primary $(<7$ years)

3. Complete primary (7 years)

4. Incomplete secondary (8-11 years)

5. Complete secondary (12 years)

6. Incomplete tertiary (13-14 years)

7. Complete tertiary (15 years)

8. Incomplete university (13-16 years)

9. Complete university (>17 years)

C. Age

1. 14 to 24 years

2. 25 to 39 years

3. 40 to 59 years

4. 60 years+

D. Economic sectors
1. Manufacturing

2. Construction

3. Trade

4. Transport

5. Finance

6. Civil service

7. Services

8. Domestic service

E. Size of company

1. Up to 5 persons

2. Between 6 and 25 persons

3. Between 26 and 100 persons

4. Between 100 and 500 persons

5. 500 persons +

6. Unknown

F. Social benefits

1. All social benefits (social security, compensation, holidays, etc.)

2. No social benefits

3. Some social benefits

Table 16 shows the calculations of the intergroup index expressed as total proportions of each contribution.

\footnotetext{
57 The breakdown may be understood in internal and external terms. As indicated by Goerlich (1999), the intergroup component measures the external portion, which is when each member of the set receives the mean per capita income for that set, while the intragroup component measures the internal inequality and is a weighted sum of the inequality indices for each of the sets, where the weightings depend on the income and population proportions of each population set.
} 
Table 16

Decomposition of inequality in wage distribution

Proportion of the intergroup contribution (\%)

\begin{tabular}{l|r|r|r|r|r|r}
\hline & $\mathbf{1 9 8 0}$ & $\mathbf{1 9 8 5}$ & $\mathbf{1 9 9 0}$ & $\mathbf{1 9 9 5}$ & $\mathbf{1 9 9 7}$ & $\mathbf{1 9 9 9}$ \\
\hline Total inequality (Theil) & $\mathbf{0 . 2 5 5 5}$ & $\mathbf{0 . 2 6 9 6}$ & $\mathbf{0 . 2 6 0 1}$ & $\mathbf{0 . 2 9 0 9}$ & $\mathbf{0 . 2 7 8}$ & $\mathbf{0 . 2 9 6 2}$ \\
\hline Sex & 3.6 & 3.7 & 1.5 & 3.1 & 2.6 & 2.1 \\
\hline Educational level & 20.1 & 17.6 & 13.8 & 20.1 & 22.6 & 20.0 \\
\hline Age & 6.9 & 5.9 & 4.5 & 6.3 & 8.1 & 6.5 \\
\hline Sector of activity & 7.8 & 5.2 & 3.4 & 6.6 & 8.2 & 8.0 \\
\hline Size of undertaking & 8.4 & 9.2 & 8.4 & 11.3 & 12.3 & 14.8 \\
\hline Social benefits & 4.2 & 5.2 & 6.4 & 9.2 & 8.3 & 11.8 \\
\hline Source
\end{tabular}

Source: author's calculations based on EPH, INDEC.

As in the majority of studies that have analysed the decomposition of inequality using the Theil index, and irrespective of the various categories into which the index breaks down, it can be seen that the majority of the inequality is accounted for by the intragroup inequality. In other words, the dispersion within each of these sets is the major cause of the inequality. Nevertheless, and taking that fact into account, various interesting conclusions can be reached on the basis of analysis of the intergroup component. Education is the most influential variable for the purposes of explaining inequality among those in waged employment, because despite a fall in 1990 it accounts for approximately $20 \%$ of the total dispersion. In other words, the differences in income between sets in accordance with their educational level accounts for rather less than a quarter of the dispersion of earned income. Taking into account the datum for 1999, if all the education groups earned the same average income, the resulting inequality would be $20 \%$ less than it actually is. The importance attached to the education variable in inequality decomposition studies has been widely diverse. In the case of Latin America, Chanduví and Diaz (1998), Cárdenas and Bernal (1998) and Ferreira and Litchfield (1998) found that education is the crucial variable for the purposes of explaining changes in inequality, its value (depending on the country concerned and the methodology used) lying in the range between $20 \%$ and $40 \%$. This regularity has also been found in more highly industrialized countries: in the case of Portugal, Cardoso (1997) found that level of education accounts for $27 \%$ of wage dispersion.

The other two relatively important variables are size of undertaking and social benefits. The former, with a significance of some $8.5 \%$ in the $1980 \mathrm{~s}$, rose to $75 \%$ during the subsequent decade, by which time it accounted for $15 \%$ of inequality. The change in this variable in the 1990s and its increasing influence may be interpreted as a clear effect of the increasingly precarious nature of the labour market, resulting from the fact that employees with no pension rebate are concentrated primarily in small undertakings, bordering on or forming part of the informal sector. On the other hand, the significance of social benefits, although less, did increase by $180 \%$ over the period as a whole, reaching $11.8 \%$ in 1999 . This 
result agrees with that obtained in the econometric analysis. Differences in sector of activity, sex and age are relatively less significant in explaining inequality in wage dispersion. 58

\section{CONCLUSIONS}

In this study, we have reviewed the factors that we believe are critical to an understanding of wage inequality in Argentina. We consider that the changes that have taken place over the past two decades have certain special features that make them an interesting subject for study, allowing an analysis of the ways in which labour reforms and economic changes in the labour market have influenced wage inequality. The main contribution made by this study, by comparison with other analyses of wage inequality, is its comprehensive approach, whereby macroeconomic, labour and institutional factors are all considered from the same standpoint, as contributory causes of inequality. Also, most of the studies that have considered the distributive aspects using data from Argentina have focused on income in general rather than exclusively on wages, so that the connection with the labour market is less clear.

We have undertaken a review of the theoretical and empirical literature covering those factors that are critical to an understanding of wage inequality. The core of the analysis in the various studies is centred on an analysis of the components of supply and demand in the labour market and, to a lesser extent, the institutional changes that have taken place in that market.

The analysis of the labour institutions and of the stages of intervention shows that convergence has focused on restrictions on the labour market, whether imposed by way of wage control, by the weak dynamic effect of the minimum wage or by specific policies intended to weaken social protection and many of the basic labour rights, all adopted on the basis of the same collective bargaining. It is for that reason that situations that could be described as atypical in a normal situation have become the typical forms of contracting in the labour market as it stands in the wake of economic crises and reforms.

In association with this process, we find that the components inherent in labour supply and demand are significant for the purposes of understanding the variations in wage inequality. We find that there is a substantial increase in demand for highly educated employees, thus increasing the premium of education. The increase is substantial for employees with 17 years' education, while the wage differentials between extreme educational levels are as high as $200 \%$. On the supply side, there has been a substantial increase in the female participation rates, resulting from changes in economic activities, the fall in incomes and the fact that male employees are being driven out of the labour market.

We have constructed three econometric models by OLS which correspond, albeit not strictly, to economic, labour and institutional variables. The regressions bear out the hypotheses that changes in these determinants have influenced the pattern of wage inequality. More specifically, the results show that improvements in the level of economic activity and

58 The relative insignificance of age is perhaps rather more surprising in relation to comparative studies of the life cycle of human resources. As was well established by Ferreira and Litchfield (1998), there is considerable evidence to suggest a significant correlation between income and age, so that disparities between the age groups might be expected. 
investment reduce levels of inequality, while the unemployment rate has a regressive effect on them. We found an important change in the price trend during the period analysed. Whereas the 1980s, characterized by high levels of inflation, had a positive impact in wage inequality, during the 1990s, with almost insignificant price variations, the correlation became negative, both in the period following the inflation crisis and in longer-term policies. What is new about this finding is that both effects were regressive, although for different reasons. The primary cause is the impact of the hyperinflationary period, while in the 1990s the effect is due to the costs associated with the price stabilization programmes.

Among the labour factors, we have noted the importance of wages by educational levels. The results show that the greater the wage gap between skilled and unskilled workers, the higher the level of wage inequality, a hypothesis that would verify the change in demand and its impact on the distributive aspect. Another of the results of the new labour structure was approximated by informality. The result is a positive coefficient which indicates the existence of a regressive correlation between the informal sector and wage inequality. This is not a regular finding in the empirical studies, nor does it directly corroborate the hypothesis of substitution between men and women in the labour market.

The results of the institutional model show that the greater the importance of the labour institutions, the less will be the effect of the economic changes in the labour market, especially on wages. This is verified by the significance of the minimum wage, social benefits and institutional effects for the purposes of explaining inequality.

The result of years of policies of reform and adjustment was a degree of economic stability which entails high social costs, one of the most significant of which is inequality. This must not be understood as being solely a result of specific policies or, from an egalitarian standpoint, as being an end in itself. To the contrary, inequality should be seen as a phenomenon that foreshadows marginalization, as a road that leads to social vulnerability and extreme poverty, and as a loss of well-being for broad sectors of society. Furthermore, the processes of increases in wage inequality impose serious restrictions on any attempt to dynamize the economy, dynamism here being understood not merely as the achievement of economic stability but as an objective of economic and social development that is sustainable in the long term. But any restriction involves a hidden opportunity, which is rooted in the existence of a historical memory of a country that is integrated, socially and otherwise, and has a high level of cultural capital, factors that are necessary to reverse this process. For all those reasons, we believe that the analysis of the characteristics of inequality in Argentina is relevant.

The policy recommendations that can be inferred from this study are that a sound macroeconomic policy not only produces increases in output levels, falling unemployment and higher productivity but also contributes to the stability of the wage distribution, improving the welfare of the employees. Similarly, public policies must be geared not only to the advancement of the economic growth stimulated by the market but also to ensuring the distribution of the benefits of that growth, which can be achieved by strengthening the role of the labour institutions and reversing the processes of informality and deficient social protection. Finally, a minimum wage policy that encompasses all employees, as well as acting as a containment factor in the lower part of the wage distribution, produces positive effects in terms of reducing wage inequality.

Future studies should take account of the hypothesis of polarization in the labour market, something which in many studies is seen as a factor linked to wage inequality, and it 
would also be necessary to analyse the effect of the labour institutions, primarily the minimum wage, on employment, in particular whether there are groups prejudiced in terms of job losses by the introduction of the minimum wage. 


\section{BIBLIOGRAPHY}

Adelman, I. and Morris, T. 1974. “¿Quién se beneficia con el desarrollo económico?”, in Foxley, A. (ed.) 1974. Distribución del ingreso (Mexico, Fondo de Cultura Económica).

Altimir, O. 1986. "Estimaciones de la distribución del ingreso en la Argentina, 1953-1980", in Desarrollo Económico, Vol. 25, No 100.

Altimir, O. 1997. "Desigualdad, empleo y pobreza en América Latina: efectos del ajuste y del cambio en el estilo de desarrollo", in Desarrollo Económico, Vol. 25, No 145.

Altimir, O. and Beccaria, L. 1999. "El mercado de trabajo bajo el nuevo régimen económico en Argentina", in Serie Reformas Económicas, No 28 (ECLAC).

Atkinson, A. 1970. "On the measurement of inequality", in Journal of Economic Theory, Vol. 2.

- 1975. The economics of inequality (London, Oxford University Press).

—. 1997. "Bringing income distribution in from the cold", in The Economic Journal, No 107 (Cambridge).

Barbeito, A. and Rodriguez, C. 1995. 'Empleo, remuneración del trabajo y distribución del ingreso: o acerca del cuento de la buena pipa", in Minsburg, $\mathrm{N}$ and Valle, H. (eds.), Argentina hoy: crisis del modelo (Buenos Aires, Letra Buena).

Battistini, O. 1999. "Representación sindical: una forma sin contenido" (mimeo).

Bazen, S. and Skourias, N. 1997. "Is there a negative effect of minimum wages on youth employment in France", in European Economic Review, No 41.

Beache, C. and Slotsve, G. 1996. Are we becoming two societies? income polarization and the myth of the declining middle class in Canada (Toronto, C.D Howe Institute).

Beccaria, L. 1991. 'Distribución del ingreso en Argentina: explorando lo sucedido desde mediados de los setenta", in Desarrollo Económico, Vol. 31, No 123.

-. 1996. "Reconversión, mercado de trabajo y distribución del ingreso", in Informe de Coyuntura del Centro de Estudios Bonaerense, Nos 57-8 (La Plata).

Bernard, A. and Jensen, J. 1998. "Understanding increasing and decreasing wage inequality", in NBER Working Paper Series, No 6571.

Blau, F. and Kahn, L. 1996. "International differences in male wage inequality: institutions versus market forces" in Journal of Political Economy, Vol. 104, No 4.

Blejer, M. and Guerrero, I. 1990. "The impact of macroeconomic policies on income distribution: an empirical study of the Philippines", in Review of Economics and Statistics, No 72.

Blinder, A. and Esaki, H. 1978. "Macroeconomic activity and income distribution in the postwar United States", in Review of Economics and Statistics, No 60.

Borjas, G. et al. 1992. "On the labor market effects of immigration and trade", in Borjas, G and Freeman, R. (eds), Immigration and work force (Chicago, University of Chicago/NBER).

Bound, J. and Johnson, G. 1992. "Changes in the structure of wages in the 1980s: an evaluation of alternative explanations", in The American Economic Review, Vol. 82, No 3.

Brown, C. et al. 1982. "The effect of the minimum wage on employment and unemployment", in Journal of Economic Literature, Vol. 20.

Bulmer-Thomas, V. 1996. The new economic model in Latin America and its impact on income distribution and poverty, Institute of Latin American Studies Series (London, University of London).

Bustelo, E. and Minujin, A. 1996. "La política social esquiva", paper given at the First Congress of the Centro Interamericano para el Desarrollo (CLAD) (Rio de Janeiro).

Cappellety, B. et al. 2000. Actores sociales y Estado en la formación profesional de la Argentina en los 90 (Montevideo, CINTERFOR/ILO). 
Cárdenas, M. and Bernal, R. 1998. "Changes in the distribution of income and the new economic model in Colombia”, Serie Reformas Económicas, No 36 (ECLAC).

Card, D. 1992. "The effect of unions on the distribution of wages: redistribution or relabeling?", NBER Working Paper No 4195.

- and Krueger, A. 1995. Myth and measurement: the new economics of the minimum wage (Princeton, Princeton University Press).

Cardoso, A. 1997. "Workers or employers: who is shaping wage inequality?", in Oxford Bulletin of Economics and Statistics, Vol. 59, No 4.

Castel, R. 1997. La metamorfosis de la cuestión social (Barcelona, Paidos).

Castells, A. and Bosch, N. 1998. El futuro del estado de bienestar: algunas líneas de reflexión (Madrid, Civitas).

Chanduví, J. and Diaz, J. 1998. 'Desigualdad del ingreso y del gasto en el Perú antes y después de las reformas estructurales", in Serie Reformas Económicas, No 34 (ECLAC).

Cornia, G. 1999. "Liberalization, globalization and income distribution", The United Nations University (Helsinki, Wider).

Cortés, R. 1996. "Argentina: reestructuración económica e impacto en el mercado de trabajo", in Informe de Coyuntura del Centro de Estudios Bonaerense, No 57-8 (La Plata).

—. 1996b. "Regulación institucional y fragmentación de la fuerza de trabajo: Argentina 19801990" in Figueiredo, J. (ed.) 1996. Las instituciones laborales frente a los cambios en América Latina (Ginebra, Instituto Internacional de Estudios Laborales).

—. and Marshall, A. 1999. "Estrategia económica, instituciones y negociación política en la reforma social de los '90", in Desarrollo Económico, Vol. 39, No 154.

David, S. and Haltiwanger, J. 1991. "Wage dispersion between and within US manufacturing plants, 1963-86", in Brooking Papers, Economic Activity: Microeconomics, 1991.

Dinardo, J. and Lemieux, T. 1997. "Diverging male wage inequality in the United States and Canada, 1981-8: do institutions explain the difference?", in Industrial and Labor Relations Review, Vol. 50, No 4.

Dolado, J. et al. 2000. "The role of the minimum wage in the welfare state: an appraisal", in CEPR Discussion Paper No 2452.

Elliot, R. and Bender, K. 1997. 'Decentralization and pay reform in central government: a study of three countries", in British Journal of Industrial Relations, No 35.

Feldman, S. 1995. "Contratos laborales de trabajo promovidos: su uso en el sector privado", in Estudios del Trabajo, No 8/9.

Ferreira, F. and Litchfield, L. 1998. 'Calm after the storms: income distribution in Chile, 1987-94”, World Bank Policy Research Working Paper No 1960.

Filmus, D. 1996. Estado, sociedad y educación en Argentina de fin de siglo: procesos y desafios (Buenos Aires, Troquel).

Fitoussi, J.-P. 1994. "Wage distribution and unemployment: the French experience", in The American Economic Review, May (Nashville).

Forbes, C. 2000. "Skill classification does matter: estimating the relationship between trade flows and wage inequality", MIT Working Paper.

Fortin, N. and Lemieux, T. 1997. "Rank regressions, wage distributions, and the gender gap", in The Journal of Human Resources, Vol. 33, No 3.

-; - . 1997a. "Institutional changes and rising wage inequality: is there a linkage", in The Journal of Economic Perspectives, Vol. 11, No 2.

Freeman, R. 1980. "Unionism and the dispersion of wages", in Industrial and Labor Relations Review, Vol. 34, No 1.

-. and Katz, L. 1994. "Rising wage inequality: the United States vs. other advanced countries", in Freeman, R. 1994, Working under different rules (New York, Russell Sage Foundation). 
—. 1996. "The minimum wage as a redistributive tool", in Economic Journal, No 106.

-. 1996a. "Labour market institutions and earnings inequality", in New England Economic Review, May/June 1996.

Frenkel, R. 1984. 'Salarios industriales e inflación en el período 1976-82', in Desarrollo Económico, Vol. 24, No 95.

—. 1986. "Salarios e inflación en América Latina: resultados de investigaciones recientes en la Argentina, Brasil, Colombia, Costa Rica y Chile", in Desarrollo Económico, Vol. 25, No 100.

—. and González, M. 1999. "Apertura comercial, productividad y empleo en Argentina", in Tokman, V. and Martínez, D., Productividad y empleo en la apertura económica (Lima, ILO).

Galbraith, J. 1997. "Inequality and unemployment: an analysis across time and countries", The University of Texas at Austin, Working Paper.

Galiani, S. and Sanguinetti, P. 2000. "Wage inequality and trade liberalization: evidence from Argentina", mimeo.

Gerchunoff, P. and Llach, L. 1998. El ciclo de la ilusión y el desencanto: un siglo de políticas económicas argentinas (Buenos Aires, Ariel).

Goerlich, F. 1998. "Desigualdad, diversidad y convergencia: (algunos) instrumentos de medida", in Instituto Valenciano de Investigaciones Económicas, Working Document No 53.

—. 1999. "Dinámica de la distribución de la renta, 1955-95: un enfoque desde la óptica de la desigualdad", in Revista de Estudios Regionales, No 53.

Gonzáles, M and Menendez, A. 1999. "What is the impact of unemployment on the increasing income inequality in Argentina?", mimeo.

Goldin, A. 1999. "Evolución reciente de la negociación colectiva en la Argentina", in Revista Trabajo y Seguridad Social, No 7.

Goux, D. and Maurin, E. 2000. "The decline in demand for unskilled labor: an empirical analysis method and its application to France", in The Review of Economics and Statistics, Vol. 82, No 4.

Gwynne, R. and Kay, C. 2000. "Views from the periphery: futures of neoliberalism in Latin America", in Third World Quarterly, Vol. 21, No 1.

Hidalgo, J. 1999. Mercado de trabajo y convertibilidad: los impactos de los cambios en el mercado laboral argentino (Santa Fé, Universidad Nacional del Litoral).

Hyman, R. 1999. "An emerging agenda for trade unions", Discussion Papers 98/1999 (Geneva, International Institute for Labour Studies).

Jäntti, M. 1994. "A more efficient estimate of the effects of macroeconomic activity on the distribution of income", in The Review of Economics and Statistics, No 66.

Juhn, C and Kim, D. 1995. "The effects of rising female labor supply on male wages", NBER Working Papers, No 5236.

Kahn, L. 2000. "Wage inequality, collective bargaining and relative employment from 1985 to 1994: evidence from fifteen OECD countries", in The Review of Economics and Statistics, Vol. 4, No 82.

Kanbur, R and Lusting N. 1999. "Why is inequality back on the agenda?", Inter-American Development Bank Working Paper.

Katz, L. y Murphy, M. (1992). 'Changes in relative wages, 1963-1987: Supply and demand factors", in Quarterly Journal of Economics, Vol. 107.

Krueger, A. 1993. "How computers have changed the wage structure: evidence from microdata", in Quarterly Journal of Economics, Vol. 108, No 1.

Krugman, P. and Obstfeld, M. 1994. Economía internacional: teoría y política (Madrid, McGraw-Hill). 
Kuhnle, S. 1997. "La reconstrucción política de los estados de bienestar", in Moreno, L. (ed.), Unión Europea y estado de bienestar (Madrid, CSIS).

Lanyi, A. 1987. 'Problemas de los flujos de capital a países en desarrollo", in Finanzas y Desarrollo, Vol. 24, No 3.

Larrañaga, O. 1999. "Distribución de ingresos y crecimiento económico en Chile", Serie Reformas Económicas, No 35 (ECLAC).

Lee, D. 1999. "Wage inequality in the United States during the 1980s: rising dispersion or falling minimum wage", in The Quarterly Journal of Economics, August.

Lewis, H. 1986. Union relative wage effects: a survey (Chicago, University of Chicago Press).

Llach, J. and Llach, L. 1998. "Cancelando la hipoteca. Hiperinflación, reforma de la economía, empleo y desempleo en la Argentina de los 90", in Banco Interamericano de Desarrollo, Working Paper No. 385.

- and Montoya, S. 1999. "En pos de la equidad: la pobreza y la distribución del ingreso en el Area Metropolitana de Buenos Aires: diagnóstico y alternativas de políticas”, mimeo.

Novick, M. 2000. "Reconversión segmentada en la Argentina: empresas, mercado de trabajo y relaciones laborales a fines de los '90", in De la Garza Toledo (ed.), Reestructuración productiva, mercado de trabajo y sindicatos en América Latina (Buenos Aires, Clacso).

Machin, S. and Manning A. 1996. "Employment and the introduction of a minimum wage in Britain", in The Economic Journal, No 106, May.

Machin, S. 1997. "The decline of labour market institutions and the rise in wage inequality in Britain", in European Economic Review, Vol. 41.

MacPhail, F. 1998. "Increased earnings inequality and macroeconomic performance: the case of Canada in the 1980s", in International Review of Applied Economics, Vol. 12, No 3.

—. 2000. "What caused earning inequality to increase in Canada during the 1980s?", in Cambridge Journal of Economics, No 24.

Marshall, A. 1995. 'Mercado de Trabajo y Distribución del Ingreso: efectos de la política económica 1991-4", in Realidad Económica, No 129.

-. 1995b. "Regímenes institucionales de determinación salarial y estructura de salarios, Argentina 1976-1983", in Desarrollo Económico, Vol 35, No.138

—. 1997. "Empleo en la Argentina, 1991-7: ¿Nuevas pautas de comportamiento después de la liberalización económica?", Working Paper No 79, Equipo Multidisciplinario para Argentina, Brasil, Chile, Paraguay y Uruguay (ILO).

Minujin, A. and Kessler, G. 1995. La nueva pobreza en Argentina (Buenos Aires, Planeta).

Montoya, S. 1998. Mercado de trabajo y política económica. Perspectivas, in Lindemboin, J. (ed.) 1998. El desafío del empleo a finales del siglo XX. Cuadernos del CEPED $\mathrm{N}^{\mathrm{o}} 2$, Instituto de Investigaciones Económicas, Facultad de Ciencias Económicas, Universidad de Buenos Aires.

Monza, A. and Lopez, N. 1995. 'Un intento de estimación del sector informal urbano en la Argentina" in Desarrollo Económico, Vol. 35 No. 139.

Moss, P. 1997. "Earning inequality and the quality of jobs: the status of current research, and proposals for an expanded research agenda", Center for Industrial Competitiveness, Working Paper No 198.

Neuman, D. and Wascher, W. 1999. "A cross-national analysis of the effects of minimum wage on youth employment", NBER Working Paper Series, No 7299.

Nolan, B. 1990. "Macroeconomic condition and the size distribution of income: evidence from the United Kingdom", in Journal of Post Keynesian Economics, Vol. 11, No 2.

ILO. 1998. "OIT Informa”, Panorama Laboral '98 (Buenos Aires, ILO).

—. 1997. Panorama Laboral 1997 (Lima, ILO). 
—. 1997. World labour report 1997-98: industrial relations, democracy and social stability (Geneva, ILO).

Psacharopoulos, G. 1985. "Returns to education: a further international update and implications", in Journal of Human Resources, Vol. 4, No 20.

Rabinovich, A. 1999. "¿Qué tanto explica la globalización?”, in Revista Argentina de Economía y Ciencias Sociales, Vol. 3, otoño 1999.

Rawls, J. 1971. Teoría de la justicia (Madrid, Fondo de Cultura Económica).

Richarson, D. 1997. "Changes in the distribution of wages in Canada, 1981-92", in Canadian Journal of Economics, Vol. 30, No 3.

Robertson, R. 2000. 'Trade liberalization and wage inequality: Lessons from the Mexican experience", in World Development, Vol.23 No 6.

Rowthorn, R. and Ramaswamy, R. 1997. "Deindustrialization: causes and implications", IMF Working Paper.

Sanchez, C. and Giordano, O. 1988. "El salario mínimo en Argentina: alcances y evolución 1964-88", Proyecto Gobierno Argentino - Programa de las Naciones Unidas para el Desarrollo - ILO Working Paper No 18.

Salama, P. and Valier, J. 1996. Neoliberalismo, pobrezas y desigualdades en el tercer mundo (Buenos Aires, Miño and Dávila-Ciepp).

Shorrocks, A. 1980. "The class of additively decomposable inequality measures", in Econometrica, Vol. 48, No 3

Székely, M. and Londoño, J. 1998. "Sorpresas distributivas después de una década de reformas: Latinoamérica en los 90", in Banco Interamericano de Desarrollo, Working Paper No 352.

Szretter, H. 1993. "Negociación salarial por productividad: alcances y contenidos", in Ministerio de Trabajo y Seguridad Social, Informe No 7, Buenos Aires.

Tokman, V. 1998. Panorama del empleo en América Latina, in Lindemboin, J. (ed.) 1998. El desafío del empleo a finales del siglo XX. Cuadernos del CEPED $\mathrm{N}^{\circ}$ 2, Instituto de Investigaciones Económicas, Facultad de Ciencias Económicas, Universidad de Buenos Aires.

Topel, R. 1997. "Factor proportions and relative wages: the supply-side determinants of wage inequality", in The Journal of Economic Perspectives, Vol. 11, No 2.

Tzannatos, Z. 1999. "Women and labor market changes in the global economy: growth helps, inequalities hurt and public policy matters", in World Development, Vol. 27, No 3.

Williamson, J. 1996. "The Washington consensus revisited", Main Papers, Development Thinking and Practice Conference (Washington).

Zubiri, I. 1985. "Una introducción al problema de la medición de la desigualdad", in Hacienda Pública Española, No 95. 